\title{
THE FEDERAL RETAIL SALES TAX THAT WASN'T: AN ACTUAL HISTORY AND AN ALTERNATE HISTORY
}

\author{
LAWRENCE A. ZELENAK*
}

INTRODUCTION

In 1939, on the eve of the defense buildup preceding the entry of the United States into World War II, only one American in twenty was an income taxpayer or the dependent of an income taxpayer. ${ }^{1}$ By the end of the war in 1945, 74.2\% of the population was covered by the income tax. ${ }^{2}$ The wartime conversion of the income tax from an elite tax to a mass tax is arguably the most important moment in the history of the federal income tax; it is rivaled only by the creation of the tax in 1913.

Although some form of mass federal taxation was imperative for the financing of the war, a mass income tax was not inevitable. But for the intransigent opposition of the Roosevelt Administration, Congress would almost certainly have enacted a federal retail sales tax during the war-perhaps in addition to the conversion of the income tax to a mass tax, but perhaps as the only form of mass taxation aimed at paying for the war. Although both the general public and opinion leaders supported a wartime sales tax, and although Congress several times came close to enacting such a tax, Congress could not overcome the opposition of President Franklin Delano Roosevelt and his Treasury Department.

The President's hostility to a sales tax was puzzling. He objected to a sales tax on distributional grounds, yet the combined distributional impact of a class income tax and a retail sales tax need not have differed significantly from the distributional impact of the mass income tax, which the President supported. The wartime federal tax structure, as shaped by the Roosevelt Administration's opposition to a sales tax, has endured. The federal income tax remained a mass tax after the end of the war and remains a mass tax today, and the United States has never adopted a federal retail sales tax (or value-added tax (VAT)).

Copyright (C) 2009 by Lawrence A. Zelenak.

This Article is also available at http://www.law.duke.edu/journals/lcp.

* The Pamela B. Gann Professor of Law, Duke University School of Law.

1. LAWRENCE H. SELTZER, THE PERSONAl EXEMPTIONS IN THE InCOME TAX 62 tbl.9 (1968).

2. Id. 
Part II of this article describes the wartime debates among proponents of different methods of federal mass taxation-conversion of the income tax to a mass tax, enactment of a federal retail sales tax, or both. Following the presentation of that history, part III explores a counterfactual question: How differently would the wartime and postwar federal tax structures have developed if Roosevelt had not blocked the enactment of a sales tax? The only answer that can be given with a high level of confidence is that Congress would have enacted a sales tax at some point during World War II. It is not clear whether that sales tax would have been in addition to, or instead of, the conversion of the income tax from a class tax to a mass tax. It is also not clear whether, if the United States had emerged from World War II with a two-tax structure - consisting of a retail sales tax and a class income tax-that structure would have endured to the present day.

The persistence of the two-tax structure seems sufficiently plausible, however, to motivate the counterfactual question posed by part IV: On the reasonable assumption that the distributional impact at war's end of a retailsales-tax-plus-class-income-tax would not have differed significantly from the distributional impact of the actual mass income tax, how great would have been the practical difference during the subsequent decades between the actual mass income tax and the alternative two-tax system? This question has relevance beyond the attempt to discern the long-term impact of Roosevelt's opposition to a retail sales tax. There is interest today in the possibility of returning the federal income tax to its prewar status as an elite tax and introducing a federal VAT to replace the revenue lost by narrowing the scope of the income tax. The analyses presented in part IV should be useful in predicting the long-term collateral consequences of the adoption of such a proposal, as well as in evaluating the lasting effects of the actions of the Roosevelt Administration. Part IV concludes that the use of the mass income tax rather than a two-tax system has made a significant difference in several areas, including the distribution of the benefits of postwar tax cuts and the burdens of postwar tax increases; public perceptions of the nature of the relationship between taxpayers and the federal government; the proliferation of tax subsidies targeted at particular categories of nonbusiness expenditures, ranging from first-time homebuyers to hybrid cars; income support for low-wage workers with dependent children; and federal policy toward homeownership. On the other hand, it seems likely that the choice of a mass income tax over a retail sales tax has had little effect on federal policy with respect to health insurance and employer-provided pensions. Part V briefly concludes.

II

\section{The WARTIME SAles-TAX Debates}

Even before he became President, Franklin Roosevelt set himself firmly against a federal sales tax. In the final days of the Hoover Administration, Congress became seriously interested in enacting a manufacturers' sales tax, 
encouraged by rumors that Roosevelt favored such a tax. ${ }^{3}$ Roosevelt quickly killed those rumors-and the sales tax-by sending friends to Washington to "express[] amazement and some indignation over the rumors." According to his messengers, Roosevelt was "horrified" at the suggestion that he would support a sales tax. ${ }^{5}$ Roosevelt's attitude remained the same throughout the Great Depression. In his 1938 State of the Union Message, for example, he attacked opponents who argued for tax cuts for the wealthy, describing them as "the same complainants who would impose the type of flat sales tax which places the burden of government more on those least able to pay and less on those most able to pay." With Roosevelt adamantly opposed to any sort of general sales tax, sales taxes were absent from federal tax-policy discussions during his presidency throughout the 1930s.

With the revenue demands of the defense buildup preceding the United States' entry into World War II, however, federal sales-tax proposals reemerged. In 1939, only 5\% of the country's population was covered by taxable income tax returns (that is, as income taxpayers or as the dependents of income taxpayers). ${ }^{7}$ So narrow a tax base would not suffice to finance the anticipated military expenditures. A move in the direction of mass federal taxation-either by enlarging the ranks of income taxpayers or by the introduction of a sales tax-was needed. The Revenue Act of 1940-enacted by Congress in June 1940, in prompt response to Roosevelt's May 1940 revenue request-lowered the personal exemption for a single taxpayer from $\$ 1000$ to $\$ 800$, and lowered the exemption for a married couple from $\$ 2500$ to $\$ 2000$ (without changing the $\$ 400$ per person exemption for dependents). ${ }^{8}$ Primarily as a result of the lowered exemptions, the percentage of the population covered by the income tax rose from $5 \%$ in 1939 to $9.4 \%$ in $1940 .{ }^{9}$ With less than $10 \%$ of the population covered, the 1940 income tax was still not a mass tax, but movement in the direction of mass taxation had begun.

By the spring of 1941 it was clear that additional revenue was needed, and the Treasury asked Congress to produce legislation that would raise $\$ 3.4$ billion of new revenue, increasing existing revenues by about one third. ${ }^{10}$ Although the President quickly reiterated his long-standing opposition to a sales tax, ${ }^{11}$ in the new context of the defense emergency a number of legislators expressed

3. James A. Hagerty, Roosevelt Opposes Sales Tax Program Urged on Congress, N.Y. TIMES, Dec. 28,1932 , at 1 .

4. $I d$.

5. Arthur Krock, Roosevelt Will Inherit Budget Responsibility, N.Y. TIMES, Jan. 1, 1933, at E1.

6. President Franklin D. Roosevelt, Annual Message to Congress (Jan. 3, 1938), in 1938 PuBLIC PAPERS AND ADDRESSES OF FRANKLIN D. ROOSEVELT 9.

7. SELTZER, supra note 1 , at 62 tbl.9.

8. Revenue Act of 1940, Pub. L. No. 76-656, 54 Stat. 516 (1940).

9. SELTZER, supra note 1, at 62 tbl.9. Real and inflationary growth in income also played a role in the increased coverage of the income tax.

10. John MacCormac, 33\% Rise in Taxes Asked by Treasury, N.Y. TiMES, Apr. 18, 1941, at 1.

11. Sales Tax Plan Brings on Clash, L.A. TimeS, Apr. 19, 1941, at 1. 
interest in a sales tax. ${ }^{12}$ Speaking for the Administration, Treasury Secretary Henry Morgenthau Jr. told the Ways and Means Committee that the requested revenue could and should be raised by increasing rates on those already subject to the income tax and by increases in an assortment of excise taxes, without either reducing income tax exemptions or enacting a sales tax..$^{13}$ Appearing before the Committee with Morgenthau, Assistant Secretary of the Treasury John L. Sullivan explained that the Treasury favored "increasing our reliance upon the ability-to-pay taxes," for only through such taxes could "tax burdens be distributed with careful regard to equity." ${ }^{14}$ Consumption taxes, including sales taxes, did not satisfy the ability-to-pay criterion: "Consumption taxes burden consumers without regard either to income or to family needs and responsibility and thus fail to meet the test of equity." ${ }^{15}$ A general sales tax, in particular, was objectionable because it would "fall more heavily on the very lowest income groups," "require the creation of an elaborate administrative structure," "add to the complexity of the Federal tax structure" if superimposed on existing excise taxes, and give rise to "Federal-State fiscal conflict."

The Administration's rejection of a sales tax did not reflect public opinion; a Gallup Poll released two weeks before the Morgenthau and Sullivan statements before the Ways and Means Committee found that $54 \%$ of respondents would support a federal sales tax (with a rate of $2 \%$ ) for defense. ${ }^{17}$ While Treasury was opposing both forms of mass taxation, others were advocating simultaneously lowering income-tax exemptions and adopting a sales tax. ${ }^{18}$ In addition to the revenue-raising potential of a sales tax, proponents stressed the effectiveness of a sales tax in reducing civilian consumption and in controlling inflation. The prominent economist Gustav Stolper, for example, argued, "It is the consumption of 100 percent of the people, not of 10 percent [covered by the income tax], that must be kept under control." ${ }^{19}$ According to Stolper, a sales tax imposed at the rate of $2 \%$ "might check the inflationist effect of the armament boom and create a sufficient incentive for saving just in those classes which government and Congress say they hope to protect." ${ }^{20}$

12. Congressmen Talk of $8 \%$ Income Tax, N.Y. TiMES, Apr. 20, 1941, at 34.

13. Hearings Before the Comm. on Ways and Means on Revenue Revision of 1941, 77th Cong. 3-5 (1941) (statement of Henry Morgenthau Jr., Sec'y of the Treasury); Henry N. Dorris, Morgenthau Urges Higher Taxes to Pay Cash and Cut Borrowing, N.Y. TIMES, Apr. 25, 1941, at 1.

14. Hearings Before the Comm. on Ways and Means on Revenue Revision of 1941, 77th Cong. 46, 47 (1941) (statement of John L. Sullivan, Assistant Sec'y of the Treasury).

15. Id. at 47.

16. Id. at 51 .

17. Federal Sales Tax Backed in Survey, N.Y. TIMES, Apr. 4, 1941, at 37.

18. Gustav Stolper, Sales Levy Recommended to Curb Civilian Consumption, N.Y. TIMES, May 4, 1941, at E8; Hearings Before the Comm. on Ways and Means on Revenue Revision of 1941, 77th Cong. 551-56 (1941) (statement of Livingston W. Houston, representing the National Association of Manufacturers).

19. Stolper, supra note 18 .

20. Id. 
The Ways and Means Committee recommended a bill along the lines requested by Treasury, ${ }^{21}$ but Chairman Robert Doughton predicted that both a sales tax and lowered income-tax exemptions would be needed the next year. ${ }^{22}$ A Los Angeles Times editorial advocating a federal sales tax speculated that the President had changed his mind on the issue: "So important a departure from prior administration policy... would hardly have been advocated by $\mathrm{Mr}$. Doughton without consultation with the President.".23

Although Treasury had not requested any increase in income-tax coverage during the April Ways and Means hearings, at the end of July the President sent Chairman Doughton a letter requesting that the Committee's bill be revised to lower the exemptions to $\$ 750$ for a single person and $\$ 1500$ for a married couple. ${ }^{24}$ "The overwhelming majority of our citizens," wrote Roosevelt, "want to contribute something directly to our defense and ... most of them would rather do it with their eyes open than do it through a general sales tax .... In other words, most Americans who are in the lowest income brackets are willing and proud to chip in directly even if their individual contributions are very small in terms of dollars. ${ }^{25}$ Doughton replied that a number of Committee members, including himself, would have been open to reducing exemptions but that the Committee had not done so because of Treasury's strenuous opposition. "I am surprised," he complained, "to learn that your views are antagonistic to those expressed so emphatically by the Treasury as the representative of the Administration." ${ }^{26}$

Ways and Means did not revise its bill in response to the President's letter. Instead, the action moved to the Senate Finance Committee, which heard from a number of sales-tax proponents. Responding to the Administration's claim that a sales tax would unfairly burden lower-income groups, the Investment Bankers Association of America proposed a retail sales tax with an exemption for necessities, a rate of $10 \%$ on luxuries, and a rate of $5 \%$ on goods that were neither necessities nor luxuries. ${ }^{27}$ The bankers' association also favored the reduction in income-tax-exemption levels the President had requested. ${ }^{28}$ In sharp contrast, the American Federation of Labor objected to any move in the direction of mass taxation; it opposed both a sales tax and any lowering of

21. Henry M. Dorris, More Detail Work: Congress Not Likely to Get Record Measure for Three Weeks Yet, N.Y TimES, July 3, 1941, at 1.

22. Sales Levy Seen in Next Tax Bill, N.Y. TimES, July 29, 1941, at 1.

23. A Federal Sales Tax; Why Not?, L.A. Times, Aug. 4, 1941, at A4. About two weeks later, the Wall Street Journal followed with its own pro-retail-sales-tax editorial. The Logic of a Sales Tax, WALL ST. J., Aug. 19, 1941, at 4. The editorial addressed the regressivity objection: "To the argument that it is objectionable because it hits the 'poor' hardest, the answer is that the government spending provides the increased earnings to meet the tax." Id.

24. Roosevelt and Doughton Letters and Morgenthau's Note, N.Y. TIMES, Aug. 3, 1941, at 33.

25. Id.

26. $I d$.

27. Hearings Before the Comm. on Finance on H.R. 5417, 77th Cong. 77-78 (1941) (statement of Harcourt Amory, Chairman, Comm. on Fed. Taxation, Investment Bankers Association of America).

28. Id. at 70 . 
income-tax exemptions. ${ }^{29}$ After twelve days of hearings, the Finance Committee reported a bill to the President's liking. It reduced income-tax exemptions to $\$ 750$ for single persons and $\$ 1500$ for married couples and did not include a sales tax; the bill was expected to add six million new taxpayers to the income tax rolls and to raise almost $\$ 3.7$ billion in new revenue..$^{30}$ The Senate version survived the conference process with only minor changes, and the President signed the bill into law as the Revenue Act of $1941^{31}$ on September $20 .^{32}$ With the lowered exemptions, the percentage of the population covered by taxable income tax returns increased dramatically, from $9.4 \%$ in 1940 to $24.7 \%$ in $1941 .^{33}$ The income tax now covered too much of the population to be considered strictly a tax on the economic elite; but with not quite a quarter of the population subject to the tax, neither was it truly a mass tax.

As the 1942 legislative season approached, with the United States finally officially at war, it was clear that even more tax revenue would be required and that some form of mass taxation was inevitable. In late December 1941, the Associated Press reported growing sentiment among members of Ways and Means in favor of a sales tax, as "less burdensome to the public generally" than the alternative of wage withholding under the income tax. ${ }^{34}$ In early January 1942, the New York Times suggested a sales tax was coming soon: "The general belief is that the bulk of new revenue will be raised through increases in the excise tax, and through the imposition of a Federal sales tax ...."35

It also appeared that Roosevelt would reluctantly accept a sales tax. In his Budget Message of January 7, 1942, he adhered to his long-standing position that a sales tax should not be a permanent part of the federal revenue structure, but he added that "in the face of the present financial and economic situation, however, we may later be compelled to reconsider the temporary necessity of such measures. ${ }^{{ }^{36}}$ A Washington Post editorial predicted that, in light of the President's concession that a sales tax may be required, "enactment of such a levy may be expected" and opined that "a general sales tax would have the great merit of producing substantial revenue and limiting consumer buying without resort to outright restrictions. ${ }^{{ }^{37}}$ A poll of the members of the National Retail Dry Goods Association found that $78 \%$ supported a general federal retail sales tax, despite the obvious disadvantages to retailers of such a tax. ${ }^{38}$

29. Id. at 1477 (statement of W. C. Hushing, Chairman, Leg. Comm., American Federation of Labor).

30. Henry N. Dorris, Senators Draft Biggest Tax Bill at \$3,672,400, N.Y. TIMES, Aug. 30, 1941, at 1.

31. Revenue Act of 1941, Pub. L. No. 77-250, 55 Stat. 689 (1941).

32. Roosevelt Signs Record Tax Bill, N.Y. TIMES, Sept. 21, 1941, at 1.

33. SELTZER, supra note 1, at 62 tbl.9.

34. Sales Tax Sentiment in Congress Gaining, L.A. TIMES, Dec. 22, 1941, at 16.

35. Henry N. Dorris, Big Tax Boosts Due When Congress Meets, N.Y. TimES, Jan. 4, 1942, at E8.

36. John MacCormac, Profit Tax of 50\% Predicted and Big Security, Excise Levy, N.Y. TIMES, Jan. 8,1942 , at 1.

37. The Sales Tax Looms, WASH. Post, Jan. 10, 1942, at X8.

38. Merchants Favor Retail Sales Tax, N.Y. TIMES, Feb. 25, 1942, at 29. 
The Treasury Department, however, was not ready to accept the inevitability of either a sales tax or a mass income tax. Appearing before the Ways and Means Committee on March 4, Secretary Morgenthau requested \$7 billion in new revenue to be raised through higher income-tax rates and higher excise-tax rates, without either a sales tax or lowered income-tax exemptions. ${ }^{39}$ Despite-or perhaps because of - the President's recent indications that he might accept a wartime sales tax, Morgenthau's denunciation of a sales tax was especially forceful:

No general sales tax is recommended, and indeed I strongly urge that no such tax be made a part of this revenue bill. The general sales tax falls on scarce and plentiful commodities alike. It strikes at necessaries and luxuries alike. As compared with the taxes proposed in this program, it bears disproportionately on the low-income groups whose incomes are almost wholly spent on consumer goods. It is, therefore, regressive and encroaches harmfully upon the standard of living. It increases prices and makes price control more difficult. It stimulates demands for higher wages and adds to the parity prices of agricultural products. It is not, as many suppose, easily collected; on the contrary, its collection would require much additional administrative machinery at a time when manpower is limited. ${ }^{40}$

Morgenthau's testimony did not receive a particularly friendly reception from the members of the Committee. Representative Harold Knutson, for example, sarcastically commented, "I do not suppose that the fact that the administration is against the sales tax is influenced at all by the fact that it would affect 30 or 40 million voters. ${ }^{.41}$ Knutson claimed, "Everybody I talk with is in favor of a sales tax, except the administration." ${ }^{42}$

As the hearings continued with other witnesses, Morgenthau held a press conference at which he argued that persons not subject to the income tax were paying substantial "hidden" levies through excise taxes and that "this group can't stand more taxes. ${ }^{\prime 3}$ Noting that an unofficial poll of the members of the Ways and Means Committee revealed majority support for "a sales tax in some form," the New York Times predicted "a fight to the finish between the Administration and Congress over the question of subjecting persons now exempt under the income tax laws to direct levies or a general sales tax."

Another idea for making a sales tax more distributionally attractive emerged in the hearings on March 11 in a colloquy between Representative Frank Carlson and W. J. Schieffelin Jr. of the New York State Chamber of Commerce. Carlson asked Schieffelin whether it would be "practicable and effective" under a sales tax to give "an exemption for each family for a certain amount of commodities"- or, as Schieffelin put it in his response, "a ration card

39. Hearings Before the Comm. on Ways and Means on Revenue Revision of 1942, 77th Cong. 1-10 (1942) (statement of Henry Morgenthau Jr., Sec'y of the Treasury). Morgenthau also asked that the Secretary of the Treasury be given authority "to begin the collection of income taxes at the source, at any time and at rates within his discretion up to 10 percent of wages and salaries." Id. at 5 .

40. Id. at 7.

41. Id. at 32 .

42. $I d$.

43. Henry N. Dorris, Says Tax Exempts “Can’t Stand More,” N.Y TimES, Mar. 10, 1942, at 14.

44. Id. 
from which he could buy without a tax." ${ }^{45}$ Despite Carlson's obvious enthusiasm for the idea, Schieffelin expressed a preference for a lower-rate tax with no exemptions.

At the request of the Ways and Means Committee, both the Treasury Department and the Staff of the Joint Committee on Taxation prepared background memoranda on policy and design issues relating to a sales tax. ${ }^{46}$ The Treasury's memorandum elaborated on Morgenthau's list of the failings of sales taxes, whereas the Joint Committee's memorandum took no position on the merits of sales taxation. ${ }^{47}$ According to members of the Ways and Means Committee, however, if the Staff of the Joint Committee had been asked for its views on the merits, "there would come from this source a recommendation for a sales tax." ${ }^{48}$

In early April, Representative Wesley Disney, claiming to have surveyed the entire House, announced that "an overwhelming majority" of the House would prefer a sales tax to the Administration's proposed tax increases. ${ }^{49}$ President Roosevelt, however, soon held a press conference at which he emphatically denounced a federal sales tax; if his opposition had softened as of his January Budget Message, it seemed to have rehardened by his April press conference. ${ }^{50}$ About a week after the press conference, the New York Times reported rumors that Chairman Doughton had told President Roosevelt that the President's revenue goal could be met only by the enactment of a sales tax..$^{51}$ According to "reliable sources," both Roosevelt and Morgenthau considered enactment of a sales tax to be probable, although they would continue to oppose it. ${ }^{52}$ As the hearings ended, the New York Times pronounced that "a fight undoubtedly impends over a move to substitute a sales tax ... for a part of the revenue expected [under Treasury's proposal] from individuals and from corporations. ${ }{ }_{53}$

The next move came from Morgenthau, and it was probably the single most important anti-sales-tax initiative taken by the Administration during the entire war; without it, there would probably have been a federal sales tax for at least the duration of the war, and perhaps for much longer. On May 7, Morgenthau

45. Hearings Before the Comm. on Ways and Means on Revenue Revision of 1942, 77th Cong. 233 (1942).

46. Department of the Treasury, Federal Manufacturers' Wholesale and Retail Sales Taxes, in Hearings before the Committee on Ways and Means on Revenue Revision of 1942, 77th Cong., 345-59 (1942); Staff of the Joint Committee on Internal Revenue Taxation, Sales Tax Data, in Hearings before the Committee on Ways and Means on Revenue Revision of 1942, 77th Cong., 2d Sess., 360-485 (1942).

47. Staff of the Joint Committee on Internal Revenue Taxation, supra note 46, at 360 ("This compilation contains merely data and reaches no conclusions as to the merits or demerits of a general sales tax.").

48. Henry N. Dorris, $\$ 3,680,000,000$ Yield Seen in Sales Tax, N.Y. TIMES, Mar. 17, 1942, at 15.

49. Shift Toward Sales Tax Indicated by House Survey, L.A TIMES, Apr. 3, 1942, at 1.

50. Henry N. Dorris, President Says Tax on Sales Is Wrong; Murray Opposes It, N.Y. TIMES, Apr. 8,1942 , at 1 .

51. Takes Tax Problem to the White House, N.Y. TIMES, Apr. 16, 1942, at 34.

52. Id.

53. Tax Hearings End; Sales Tax Issue Acute, N.Y. TIMES, Apr. 18, 1942, at 28. 
presented Ways and Means with a request for an additional $\$ 1.1$ billion of revenue and a recommendation that the revenue be raised by reducing the single-person exemption from $\$ 750$ to $\$ 600$, the exemption for a married couple from $\$ 1500$ to $\$ 1200$, and the exemption for a dependent from $\$ 400$ to $\$ 300$. The proposed reductions would create almost seven million new income taxpayers. ${ }^{54}$ According to the New York Times, even Treasury tax experts had not been consulted before Morgenthau dropped his "bombshell" on the Committee..$^{55}$ The Times also reported that Committee opponents of a retail sales tax had little hope of avoiding some form of mass taxation in the wake of Morgenthau's request: "[T] he proposal was said ... to have driven them virtually into a corner in which they had only the alternative of adopting a schedule of rates that would reach into virtually all incomes or accept a sales tax that would affect the economy of even the poorest wage-earner." ${ }^{\prime 66}$

What explains Morgenthau's dramatic reversal of his March opposition to lowered income-tax exemptions? Most likely he had concluded by early May that the Administration could not resist the widespread support in Congress for some form of mass taxation, and that the only way to defeat the greater evil (in the Administration's view) of a sales tax was to recommend the lesser evil of a mass income tax. The Wall Street Journal voiced exactly that suspicion in an editorial: "This newspaper cannot easily suspect Mr. Morgenthau of playing with red herrings. But it cannot help wondering whether the Administration may not wish to divert Congressional attention from the general sales tax ... by proposing this short and faltering step in the direction of taxing war-made income all down the line. ${ }^{157}$ It was not clear that Morgenthau's strategy would succeed in fending off enactment of a sales tax. For example, the Washington Post editorialized that the proposed lower exemptions were "a good beginning," but that "[t]here is still need for a substantial sales tax of a general nature that will force widespread curtailment of spending." $"{ }^{8}$

On May 13, the Ways and Means Committee voted tentatively for exemption levels similar, but not identical, to Morgenthau's request: $\$ 500$ for an unmarried taxpayer (\$100 lower than Morgenthau had proposed), $\$ 1200$ for a married couple (the same as Morgenthau's proposal), and $\$ 400$ per dependent (\$100 more than Morgenthau had proposed, and no reduction from thencurrent law). ${ }^{59}$ Despite its tentative willingness to give Treasury approximately what it wanted on the exemption issue, the Committee was not willing to recommend all the tax-rate increases requested by Treasury. On June 6, a "defiant" Committee reportedly gave the Administration an "ultimatum": It must either accept a sales tax (in addition to, rather than in lieu of, the

54. Henry N. Dorris, Morgenthau Asks Broader Tax Base, N.Y. TIMES, May 8, 1942, at 1.

55. Id.

56. Id.

57. Still Not Real War Taxing, WALL St. J., May 9, 1942, at 4.

58. Change of Heart, WASH. POST, May 8, 1942, at 14.

59. Committee Cuts Exemptions in Tax Bill to $\$ 1,200$, \$500, N.Y. TIMES, May 14, 1942, at 1. 
decreased income-tax exemptions) or accept legislation falling $\$ 2$ billion short of the Administration's revenue goal. ${ }^{60}$ The Administration responded not with acceptance of a sales tax, but with a proposal - based on a suggestion President Roosevelt had made in a speech on April 27-for a confiscatory tax system, under which no taxpayer would have after-tax income of more than $\$ 25,000$; Secretary Morgenthau remarked he was "certainly not negotiating" any compromise involving a sales tax. ${ }^{61}$

Although the Committee promptly and emphatically rejected the confiscation proposal ${ }^{62}$ it was unwilling to recommend a sales tax in the face of the Administration's continued opposition. On June 20, Chairman Doughton announced that the Committee would not even vote on the sales-tax question. ${ }^{63}$ On June 24 the Committee made its final decisions: it would send to the House a proposal that would raise about $\$ 6$ billion of revenue (almost $\$ 2.7$ billion short of Treasury's request), including the income-tax-exemption reductions the Committee had tentatively agreed to on May 13, but not including a sales tax. ${ }^{64}$ During the House debate on the Committee's bill in mid-July, Doughton told the members that Treasury had clearly indicated to him (through Randolph Paul, Special Tax Adviser to Morgenthau) that it would "rather have the bill remain short [on revenue than] have a sales tax." ${ }^{65}$ The bill-with the lowered income-tax exemptions, without a sales tax, and more than $\$ 2.4$ billion short of the Administration's revenue goal-passed the House on July 20 by a vote of 392 to $2 .^{66}$

The action on the bill then moved to the Senate. On July 23, Morgenthau testified before the Senate Finance Committee. Noting that the reduced income-tax exemptions would "affect almost seven million individuals who have never paid direct taxes to the Federal Government before," Morgenthau claimed-apparently as a matter worth celebrating - "[f]or the first time in our history the income tax is becoming a people's tax. ${ }^{167}$ Despite his newfound enthusiasm for mass taxation by way of the income tax, Morgenthau continued to oppose a sales tax. He told the Committee that the Treasury's proposals "are based upon the principle of ability to pay, and they avoid such devices as a general sales tax, which would fall with the greatest impact upon those least able to bear the burden." ${ }^{68}$ The New York Times, which had long opposed sales

60. House Insists on Sales Tax, L.A. TIMES, June 7, 1942, at 9.

61. Henry N. Dorris, Treasury Submits Income Ceiling Tax, N.Y. TIMES, June 16, 1942, at 25.

62. Henry N. Dorris, Rebuff President Twice on Tax Bill, N.Y. TiMES, June 17, 1942, at 15.

63. Sales Levy Killed; Hold-Out Tax Wins, N.Y. TiMES, June 21, 1942, at 25.

64. Henry N. Dorris, Tax Bill Finished; Totals 6 Billions; Joint Returns Out, N.Y. TIMES, June 25, 1942 , at 1.

65. Editorial, Treasury Fights Levy on Sales, L.A. TIMES, July 17, 1942, at 11.

66. Henry N. Dorris, 90\% Profits Tax Is Voted by House; Surtax Rate Kept, N.Y. TimES, July 21, 1942 , at 1.

67. Henry Morgenthau Jr., Secretary Morgenthau's Tax Statement to Senate Finance Committee, N.Y. TIMES, July 24, 1942, at 10.

68. Id. 
taxes in peacetime, responded with an editorial strongly urging the Committee to add "a moderate sales tax" to the bill. ${ }^{69}$ The editorial rejected the Administration's regressivity objection:

If we consider a sales tax, indeed, not in isolation but as a part of the whole tax system ... then the whole argument against the incidence of the sales tax as such disappears. This is obviously to look at the situation as it really is. To insist on considering the sales tax in isolation ... and to rule it out because of its own individual incidence, is to take a rigidly doctrinaire attitude instead of facing reality. ${ }^{70}$

As the Finance Committee held hearings, Committee members made salestax proposals. Commenting on a proposal by Senator John Danaher for a $10 \%$ retail sales tax, economists Meyer Jacobstein and Charles O. Hardy told the Committee the distributional impact of the tax could be modified by giving each person a book of coupons entitling the bearer to make $\$ 200$ of tax-free purchases each year. ${ }^{71}$ Senator Robert Taft proposed a $10 \%$ tax on retail sales (excluding food), combined with an increase in the income-tax-exemption levels to $\$ 1000$ (for a single person) and $\$ 2000$ (for a married couple). ${ }^{72}$ In introducing the proposal, Taft asserted that "war taxation should reach every man, woman, and child in the United States" and that his proposal would be preferable to "requiring between 50,000,000 and 60,000,000 people to make a net income tax return." "73 According to the New York Times, "Growing sentiment in favor of [a retail sales tax had] been noted within the Senate Finance Committee."

Once again, Treasury responded to the imminent prospect of a sales tax with its own proposal to raise revenue in another way. This time it was a recommendation, presented by Morgenthau to the Committee on September 3, for a more drastic reduction in income-tax exemptions-to $\$ 500$ for a single person, $\$ 1000$ for a married couple, and $\$ 250$ per dependent-and for a new "spendings tax." "The spendings tax was a cash-flow-type consumption tax, with a base of income minus savings. ${ }^{76}$ It would be superimposed on the income tax, would feature the same exemption levels as the income tax, and would be steeply progressive (with a top rate of $75 \%$ on expenditures over $\$ 10,000)$. $^{77}$ Morgenthau explained the proposal had two purposes-raising revenue and fighting inflation by "withdrawing funds otherwise available for [consumer]

69. The Case for a Sale Tax, N.Y. TIMES, July 25, 1942, at 12.

70. Id.

71. Senators Consider Higher Taxes to Pay for War, Curb Inflation, N.Y. TIMES, Aug. 22, 1942, at 26. Commenting in 1943 on this suggestion, a note writer in the Yale Law Journal expressed concern that persons whose annual expenditures were less than $\$ 200$ might sell their unused coupons at a discount. Note, Aspects of Personal Income Taxation and the 1942 Revenue Revision, 52 YALE L.J. 355, 359 (1943).

72. Sales Tax Urged by Taft as Need to Stop Inflation, N.Y. TIMES, Aug. 24, 1942, at 1.

73. Id.

74. $I d$.

75. Henry Morgenthau Jr., Morgenthau's Statement, N.Y. TIMES, Sept. 4, 1942, at 16; Treasury's Answers to Questions Explain Its Proposed Spendings Tax, N.Y. TIMES, Sept. 4, 1942, at 17.

76. Morgenthau, supra note 75.

77. Id. 
expenditure." ${ }^{, 78} \mathrm{He}$ described the proposal as "reaching into the lowest income above the level of bare subsistence." ${ }^{79}$

The Committee gave the spendings-tax portion of the proposal an extremely hostile reception. "The plan is dead," announced Senator Joseph Guffey. "Not a man on the committee is for it." ${ }^{80}$ Senator Harry Byrd described the spendings tax as having "all the evils and none of the virtues of a sales tax" and declared that "the present situation points inevitably to a graduated sales tax with a smaller tax on food and clothing." ${ }^{\prime \prime 1}$ The proposal inspired the Committee to consider, in lieu of the spendings tax, three detailed sales-tax plans (including one submitted by Treasury upon the Committee's request, "without prejudice to [Treasury's] opposition to all sales taxes"). ${ }^{82}$

Morgenthau continued to defend the spendings tax, in part by attacking a retail sales tax on the grounds that "it would fail to tax many kinds of services, it would be grossly unfair in falling upon those with only $\$ 5$ or $\$ 10$ a week of earnings, it would play havoc with price ceilings, and it would have an utterly inadequate effect in discouraging consumer spending. ${ }^{, 83} \mathrm{He}$ did not mention the possibility of using tax-free coupons to produce a sales-tax exemption as large as (or even larger than) his proposed income-tax exemptions. Despite his failure to mention tax-free coupons, the Treasury was clearly aware of that option. A Treasury Department staff memorandum dated September 9 (less than a week after Morgenthau's appearance before the Committee) responded to a question that had been posed by the President:

"Why can't a person go to the post office and buy, say, $\$ 600$ worth of stamps with which to buy goods? The first $\$ 600$ would be exempt from taxes; then you buy $\$ 600$ more and on that you would pay $10 \%$ and for each additional $\$ 600$ you would pay a higher tax." ${ }^{, 4}$

The memorandum concluded that this plan would be administratively inferior to the spendings tax, primarily because of the difficulty or impossibility of preventing trafficking in stamps: "Persons with large incomes and relatively large expenditures would benefit by purchasing stamps from those with lower incomes and lower expenditures, who could obtain stamps at relatively lower

78. $I d$.

79. Id.

80. John MacCormac, Spending Tax Gets a Cool Reception; Sales Levy Urged, N.Y. TIMES, Sept. 4, 1942 , at 1.

81. Id.

82. John MacCormac, Senators Consider 3 Sales-Tax Plans, N.Y. TimES, Sept. 5, 1942, at 1.

83. Henry Morgenthau Jr., Morgenthau on Spendings Tax, N.Y. TIMES, Sept. 5, 1942, at 26.

84. Memorandum for the President from U.S. Dep't of the Treasury, Division of Tax Research (Sept. 9, 1942) (located in Box 1; General Sales Taxes; Records of the Office of Tax Analysis/Division of Tax Research; General Records of the Department of the Treasury, Record Group 56; National Archives, College Park, MD); see also Revenue Program for 1943: Part 3-The Sales Tax and Spending Tax, U.S. Dep't of the Treasury, Division of Tax Research (internal staff memo) (December 23, 1942) ("The feasibility of a progressive retails sales tax either with or without exemptions would, therefore, ... hinge very largely on the development of a practical plan for preventing the transfer of coupons."). 
prices." 85 The memorandum did not, however, discuss the possibility of using tax-exempt stamps covering subsistence consumption without also using graduated-rate stamps for above-subsistence consumption; this more limited approach would have raised fewer trafficking concerns because few people would have consumed below the subsistence level (and thus been unable to use all their stamps themselves).

The spendings-tax proposal did not succeed in luring Committee members away from their consideration of a sales tax, and the New York Times confidently editorialized that a sales tax could not and should not be avoided: "As one alternative after another has been considered[,] the choice narrows down inevitably to a sales tax." ${ }^{\prime \prime 6}$ At the last possible moment, however, Senator Walter George, Chairman of the Finance Committee, proposed a "Victory Tax" as an alternative to a sales tax. As proposed, the Victory Tax would be imposed on the gross (not net) income of individuals, at the flat rate of $5 \%$, above a perperson annual exemption of $\$ 624$ (that is, $\$ 12$ per week), and would be collected through withholding at the source. ${ }^{87}$ This was a considerably more aggressive move toward mass taxation than Treasury's proposed reductions in income-tax-exemption levels because the Victory Tax did not allow exemptions for dependents. ${ }^{88}$ For example, a married man with two children who earned $\$ 1500$ of annual wages would not have been subject to any income tax or spendings tax under the Treasury's proposal (because of the $\$ 1000$ exemption for husband and wife, and a $\$ 250$ exemption for each child), but would have had $\$ 876$ of wages subject to the Victory Tax. ${ }^{89}$ With the Victory Tax on the table, the Committee voted against a sales tax, thirteen to six. ${ }^{90}$ As finally reported out of the Committee in early October, the bill included George's Victory Tax, the same reduced single-person and married-couple exemptions (\$500 and \$1200) as in the House bill, and (unlike the House bill) a reduction in the dependency exemption from $\$ 400$ to $\$ 300 .^{91}$ The reduced exemption levels were to be effective retroactively, to the beginning of 1942, while the Victory Tax was to become effective as of January 1, 1943.

The Victory Tax had been approved within the Committee by the narrow margin of ten to nine, and there were rumors that sales-tax proponents might

85. Division of Tax Research, supra note 84.

86. Back to the Sales Tax, N.Y. TIMES, Sept. 9, 1942, at 22.

87. C.P. Trussell, 5 P.C. "Victory Tax" on All over $\$ 624$ Brought to Fore, N.Y. TiMES, Sept. 9, 1942, at 1.

88. Id.

89. In the final version of the 1942 legislation, the regular income-tax-exemption levels were $\$ 500$ (single), \$1200 (married), and \$350 (dependent), while the Victory Tax exemption level remained \$624. Thus, a married man with two children, who earned $\$ 1900$, would have no income subject to the regular tax, but $\$ 1276$ of income subject to the Victory Tax.

90. Trussell, supra note 87.

91. Final Revision is Expected Today on $\$ 9,000,000,000$ Revenue Bill, N.Y. TIMES, Sept. 14, 1942, at 32; Henry N. Dorris, $\$ 8,000,000,000$ Tax Levy Voted by Senate Group, N.Y. TIMES, Oct. 3, 1942, at 1. 
attempt to substitute a sales tax for the Victory Tax on the Senate floor. ${ }^{92}$ Senator George told the Senate that enactment of the bill would result in a total of 46 million taxpayers in 1943-27.5 million paying the regular income tax, and another 18.5 million paying only the Victory Tax; he also told the Senate that the Victory Tax, rather than a sales tax, was "the fairest tax for the poor man that could be devised." ${ }^{\prime 3}$ After five days of debate the bill passed the Senate by a unanimous vote, with the Committee's Victory Tax and income-taxexemption levels intact. ${ }^{94}$

Not everyone was happy with the outcome. The Washington Post, for example, editorialized that a sales tax would have been a better and more popular choice than the Victory Tax: "We believe that [general sales] taxes would, in addition to being excellent revenue producers, prove much more acceptable to the public than ungraduated levies on so-called gross income added to regular income taxes." ${ }^{95}$ Northwestern University economist Paul Haensel took the same position in an article in the October issue of Taxes-The Tax Magazine. ${ }^{96}$ Haensel argued that a sales tax should be the only instrument of mass taxation. He claimed that the distributional effect of a sales tax was "surprisingly fair" when viewed in the context of the overall federal tax structure, ${ }^{97}$ and he asserted that "[a]n income tax can be properly administered only if it is an aristocratic tax levied only upon income brackets above the average. $"{ }^{98}$

The House and Senate conferees quickly agreed upon the Victory Tax and upon income-tax-exemption levels of $\$ 500$ (single taxpayers), $\$ 1200$ (married couples), and $\$ 350$ (dependents), and President Roosevelt signed the bill into law. ${ }^{99}$ The Administration, with the crucial assistance of Senator George, had again successfully resisted a sales tax, but only by accepting both a significant reduction in the regular income-tax exemptions and true mass taxation through the Victory Tax. With the reduced exemption levels (which, unlike the Victory Tax, were effective for 1942), the percentage of the population covered by taxable income tax returns rose from $24.7 \%$ in 1941 to $41.7 \%$ in $1942 .{ }^{100}$ Primarily as a result of the Victory Tax, the covered percentage rose to $68.9 \%$ in $1943{ }^{101}$ Although withholding under the regular income tax was not enacted

92. Henry N. Dorris, Senate Approves Record Tax Rates on Tentative Vote, N.Y. TIMES, Oct. 7, 1942 , at 1.

93. Id.

94. Henry N. Dorris, Senate Votes Tax Bill, 77-0, N.Y. TiMES, Oct. 11, 1942, at 1.

95. Victory Tax, WASH. PosT, Oct. 11, 1942, at B6. 614.

96. Paul Haensel, The Spendings Tax and the Victory Tax, TAXES-ThE TAX MAG., Oct. 1942, at

97. Id. at 616.

98. Id. at 618.

99. Revenue Act of 1942, Pub. L. No. 77-753, 56 Stat. 798 (1942); Roosevelt Signs Record Tax Bill, N.Y. TIMES, Oct. 22, 1942, at 22.

100. SELTZER, supra note 1, at 62 tbl.9.

101. Id. 
until mid-1943, the massive increase in covered population caused by the Revenue Act of 1942 (once the Victory Tax became effective in 1943) makes that legislation the most important milestone in the transformation of the income tax from a class tax to a mass tax.

Even as the ink was drying on the President's signature, it was widely recognized that additional revenue-raising legislation would be needed in 1943. Although the Victory Tax had made the income tax a mass tax (assuming the Victory Tax was viewed as part of the income tax, as it generally was), that did not mean it would remain the only federal mass tax. A week after the signing, Senator George declared that the Administration needed to understand that any new tax legislation would have to include a sales tax (as well as withholding under the regular income tax). ${ }^{102}$ Given the Administration's long-standing and emphatic opposition to a sales tax, the New York Times characterized George's comments as "virtually an ultimatum, serving notice that if additional taxes were to be requested, there would be a sales tax."

In late January 1943, the Brookings Institution released a forty-seven-page report, written by Charles O. Hardy, making a detailed case for a federal retail sales tax. ${ }^{104}$ The report received considerable attention in the press. ${ }^{105}$ Hardy noted that the overall federal tax system would remain progressive after the enactment of a sales tax ${ }^{106}$ Nevertheless, Hardy recommended a sales tax not as a permanent part of the federal tax system but only as a response to the wartime emergency. According to Hardy, "the very characteristics of the sales tax which make it objectionable under peacetime conditions... become positive advantages under conditions like those which now exist." ${ }^{107}$ In particular, a sales tax could be highly effective in combating inflation because it "falls primarily on income that would otherwise be devoted to consumption expenditure, and consequently has much greater efficiency in maintaining price and income stability than has the income tax." ${ }^{" 108}$ Although the case for the sales tax depended on its ability to reach the consumption of all income classes, Hardy acknowledged that subsistence consumption should not be taxed. Accordingly, he proposed exempting $\$ 200$ of annual purchases by single consumers and $\$ 350$ of annual purchases by families, with "[e]xemptions granted by issuing prepaid tax coupons directly to consumers." ${ }^{109} \mathrm{He}$ viewed

102. New Tax Bill Off Until Next March, N.Y. Times, Oct. 28, 1942, at 17.

103. $I d$.

104. Charles O. Hardy, Do We Want A Federal Sales TaX? (1943).

105. See, e.g., Editorial, General Sales Tax Urged in Congress, N.Y. TIMES, Jan. 25, 1943, at 7; Best War Tax, WASH. POST, Feb. 2, 1943, at 8 (praising the Brookings study and urging enactment of a sales tax).

106. HARDY, supra note 104, at 14.

107. Id. at 2 .

108. Id. at 9 .

109. Id. at 27. 
with equanimity the possibility that very poor persons "might get a small subsidy by selling part of their coupons." "110

Hardy conceded that his goals of raising revenue and "cutting down the consumption expenditures of the mass of the population" $" 111$ could be accomplished by a drastic lowering of income-tax exemptions-perhaps to the same levels as under his sales-tax proposal-combined with expanded incometax withholding at the source. ${ }^{112} \mathrm{He}$ argued, however, that a sales tax was superior to expansion of the income tax, because a sales tax would reach the "large portion of the national income [that] is paid out in ways that make it difficult to reach by income taxes." ${ }^{113}$ His concern was not with the level of income tax personal exemptions, but with the large amounts of nonwage income theoretically subject to income tax but not subject to third-party reporting. "[P]eople... who succeed in evading all or a large part of their income tax obligations," Hardy explained, "would be reached by a sales tax." Perhaps surprisingly, Hardy did not claim as an advantage of his proposal that, compared with a massive expansion of the income tax, it would spare lowerincome persons the difficulties of preparing and filing income tax returns.

For the first five months of 1943, congressional interest in the tax system was focused on what would become the Current Tax Payment Act of 1943, introducing withholding for purposes of the regular income tax. ${ }^{115}$ Without any transition relief, the move from a pay-in-arrears system to a pay-as-you-go system would have required taxpayers to pay both their 1942 income tax and their 1943 income tax in 1943. The question of how much transition relief should be granted proved highly contentious and took several months to resolve ${ }^{116}$ Congress did not finish its work on the withholding legislation until June $2 .{ }^{117}$

110. Id. at 31 . Hardy did not consider the possibility that the exemption could be provided by the government's issuing each person a check in the amount of the sales tax imposed on subsistence consumption, rather than through a coupon-based system. A check-based system would have been preferable to a coupon-based system in one significant respect: under a check-based system very poor persons (who consumed below the subsistence level) would get to keep the entire amount by which their checks exceeded the sales tax on their purchases, whereas under the coupon system the benefit of the subsidy would be shared by the very poor persons and the persons to whom they sold their unused coupons. The omission was not Hardy's alone. The possibility of administering a sales-tax exemption through cash transfers rather than coupons received no significant attention during the war, presumably because the idea of universal cash transfers from the government to individuals during a wartime fiscal emergency seemed so anomalous.

111. Id. at 37 .

112. Id. at 38-40.

113. $I d$. at 6 .

114. Id. at 7 .

115. Current Tax Payment Act of 1943, Pub. L. No. 78-68, 57 Stat. 126 (1943).

116. For a description of the controversy over this issue, see Carolyn C. Jones, Mass-Based Income Taxation: Creating a Taxpaying Culture, 1940-1952, in FUNDING THE MODERN AMERICAN STATE, 1941-1995, at 107, 128-30 (W. Elliot Brownlee ed., 1996).

117. John H. Crider, Senate Votes Tax Bill 62-19, And Sends It to the White House, N.Y. TIMES, June 3, 1942, at 1 . 
As work on the withholding legislation was winding down, legislative attention turned to Secretary Morgenthau's demand for revenue-raising tax legislation, with a goal of \$16 billion of additional revenue for the 1943-1944 fiscal year. ${ }^{118}$ The Treasury dusted off its spendings-tax proposal as a way of reaching its revenue goal, ${ }^{119}$ but Congress was no more interested than it had been the previous year. The Administration did not waver in its opposition to a sales tax. President Roosevelt told reporters he would veto a general sales tax but conceded it was possible that Congress would pass a sales tax over his veto. ${ }^{120}$

Appearing before the Ways and Means Committee on October 5, Morgenthau asked for legislation producing additional revenue of $\$ 10.5$ billion. ${ }^{121}$ Despite his request for more net revenue, he also asked for repeal of the Victory Tax (coupled with a small lowering of exemptions under the regular income tax); the effect, he told the Committee, would be to "relieve 9,000,000 hard-pressed families from tax on their incomes." Although Morgenthau emphasized that many of these families would still pay federal excise taxes and Social Security taxes, his proposal to move away from mass taxation-in the midst of the war, and in the context of a request for billions of dollars of new revenue-was quite surprising.

Growing sentiment was reported among Committee members for a sales tax, although there was still doubt whether a sales tax could be enacted over the Treasury's opposition. ${ }^{123}$ Two days after Morgenthau's testimony, a lengthy prosales-tax editorial appeared in the New York Times. ${ }^{124}$ Responding to the Administration's regressivity objection to a sales tax, the editorial claimed that the objection "disappears" if "we think of a general sales tax, as we must, as merely one part of the over-all tax structure that would result after its enactment." ${ }^{125}$ The editorial went on to point out that the regressivity objection "could be to a large extent met even within the sales tax itself" through the use of differing rates on necessities, semi-luxuries, and luxuries," or through the issuance "to each person [of] stamps to be paid out in lieu of sales taxes, which would be sufficient to cover that person's minimum subsistence needs." 126 The Wall Street Journal reported that "there is little doubt that the sales tax today could command a majority vote of the Ways and Means Committee," if the veto

118. John H. Crider, Abating Clarified, Tax Bill Is Shaped for Report Today, N.Y. TIMES, May 28, 1943 , at 1 .

119. John MacCormac, Treasury Revises Its Spendings Tax, N.Y. TIMES, June 4, 1943, at 22.

120. John H. Crider, Roosevelt Denies Shift on Savings, N.Y. TIMES, June 12, 1943, at 1.

121. Hearings Before the Comm. on Ways and Means on Revenue Revision of 1943, 78th Cong. 5 (1943) (statement of Henry Morgenthau Jr., Sec'y of the Treasury).

122. Id. at 6 .

123. Samuel R. Bledsoe, Sales Tax Is Urged as Treasury Plan Faces Rejection, N.Y. TIMES, Oct. 6, 1943 , at 1 .

124. Editorial, For a Sales Tax, N.Y. Times, Oct. 7, 1943, at 22.

125. Id.

126. Id. 
threat were removed. ${ }^{127}$ As the Ways and Means hearings continued, Senator George told reporters that if nine million persons were removed from the tax rolls by repeal of the Victory Tax, they should be taxed instead by a sales tax. ${ }^{128}$

On October 12, Treasury provided Ways and Means with "Considerations Respecting a Federal Retail Sales Tax." ${ }^{129}$ The paper, in more than 170 pages, discussed the various proposals that had been made to address regressivity concerns. Regarding the proposal for different rates for necessities, semiluxuries, and luxuries, the paper remarked that "[t]he problem of selecting the articles and services to be placed in the various rate groups would be a difficult one" and concluded that "a uniform rate would appear preferable to a differential rate structure." ${ }^{130}$ The paper also cited serious faults in proposals for stamp-based or coupon-based exemptions:

The use of a personal-exemption system would add greatly to the administrative requirements of enforcing a sales tax.... The abuses which might arise under an exemption system (for example, counterfeiting of tax coupons, collusion, misrepresentation and falsification) are potentially great and would have to be guarded against in order to maintain confidence in the tax system. Finally, the nature and form of the exemption itself may be objectionable. It may be difficult to justify a sales-tax rebate to everyone irrespective of need in order to protect only a minority of the population. ${ }^{131}$

The paper also considered the possibility of an exemption system limited to those with low incomes, but concluded that "the size of the administrative requirements appears to be prohibitive." ${ }^{132}$ Finally, the paper discussed the possibility of a sales tax with rates graduated according to the amount of a consumer's purchases; such a tax would be "collected in the first instance by selling coupons to consumers at rates which increase with the amount of their taxable purchases." ${ }^{133}$ The paper rejected this possibility on various administrative grounds. Most fundamentally, "There appears to be no satisfactory method of controlling transfers of coupons and, consequently, of enforcing the graduated tax rate structure." ${ }^{134}$ In sum, Treasury contended that there was no administratively feasible way of achieving an acceptable distribution of the burdens of a retail sales tax.

Despite the Treasury paper, support for a sales tax continued to grow in Congress. ${ }^{135}$ The New York Times claimed that "more and more members of

127. Sales Tax Sentiment Grows in House Group with Former Opponents Beginning to Waver, WALL ST. J., Oct. 8, 1943, at 3.

128. George Suggests Sales Tax in Place of the Victory Tax, N.Y. TIMES, Oct. 10, 1943, at 1.

129. Considerations Respecting a Federal Retail Sales Tax, Hearings Before the Comm. on Ways and Means on Revenue Revision of 1943, 78th Cong. 1095-1272 (1943) (report of the Division of Tax Research, Treasury Department).

130. Id. at $1149-50$.

131. Id. at 1169.

132. Id. at 1173 .

133. Id. at 1174 .

134. Id. at 1178 .

135. Some members of Congress may have noticed a pro-sales-tax article by the prominent Princeton economist Harvey Lutz, which appeared in October 1943. See Harvey L. Lutz, The Small 
Congress are wondering whether a federal sales tax is not about the only practical way to raise anything like the $\$ 10,500,000,000$ which the Treasury has asked for in new revenue." ${ }^{136}$ The same story speculated, "In all probability, this country would already have had a sales tax had it not been for the strong stand against it in the Treasury and at the White House." In the end, Ways and Means was unwilling to oppose the Administration on the issue. On October 28 the Committee rejected - by a vote of sixteen to eight - a proposal for a $10 \%$ retail sales tax with a $\$ 400$ coupon-based exemption for a typical family, causing Chairman Doughton to declare that the sales-tax issue was dead. ${ }^{137}$

Less than a week after Doughton's pronouncement, the Gallup Poll released the results of a new survey indicating that respondents favored "a national sales tax on everything people buy" over "increasing everybody's income taxes," by $53 \%$ to $34 \% .{ }^{138}$ According to a Wall Street Journal editorial, "The situation seems to exemplify an opposition between the Administration and public opinion more clear-cut and simple, perhaps, than anything of the kind commonly occurring in our politics in the recent past." ${ }^{139}$ Writing in favor of a sales tax in the Washington Post, economist Gustav Stolper claimed that "the debate about the sales tax [that is, the Administration's opposition to the sales tax] ceases to be rational."

But the Ways and Means Committee did not reconsider its rejection of a sales tax. On November 11 it produced a bill without a sales tax, raising only $\$ 2.1$ billion in new revenue-more than $\$ 8$ billion short of the Administration's request. ${ }^{141}$ The bill integrated the Victory Tax with the regular tax and reduced its rate from $5 \%$ to $3 \%$, but it did not remove nine million payers of the Victory Tax from the tax rolls as Treasury had proposed. For purposes of the 3\% tax, the exemption levels were $\$ 500$ for a single person, $\$ 700$ for married persons, and $\$ 100$ for each dependent; for all other purposes, the bill retained the exemption levels of current law ( $\$ 500, \$ 1200$, and $\$ 350$ respectively). ${ }^{142}$

A story in the New York Times described the standoff between the House and the Administration, as the House offered to approach the Administration's revenue goals only with a sales tax and the Administration refused to accept a sales tax:

Income and the Sales Tax, 10 TAX REV. 37 (Oct. 1943) (arguing for the introduction of a sales tax without an exemption for subsistence consumption, and for an accompanying increase in income-taxexemption levels).

136. Samuel R. Bledsoe, Support for Sales Tax Growing in Congress, N.Y. TiMES, Oct. 17, 1943, at E6.

137. Samuel R. Bledsoe, Sales Tax Beaten in Committee, 16-8, N.Y. TIMES, Oct. 29, 1943, at 3.

138. George Gallup, Sales Tax Leads in Gallup's Poll, N.Y. TIMES, Nov. 3, 1943, at 23.

139. The Real Sales Tax Issue, WALL ST. J., Nov. 4, 1943, at 6.

140. Gustav Stolper, Sales Tax Held Least Painful Levy for the Poor, WASH. PosT, Nov. 11, 1943, at 15.

141. Samuel B. Bledsoe, Agree on Tax Bill for \$2,142,900,000, N.Y. TIMES, Nov. 12, 1943, at 38.

142. Godfrey N. Nelson, Top Brackets Let Tax Exceed Income, N.Y. TIMES, Nov. 28, 1943, at S7. 
A sales tax apparently is about the only method whereby the pending bill could be raised to a figure approximating $\$ 8$ billion. A $10 \%$ levy to raise around $\$ 6$ billion has been proposed. If the Administration would agree[,] Congress probably would put through such a tax without too much hesitation. But the Administration is adamant against the sales tax, arguing that it is an unjust, inequitable levy because it would fall hardest on the low income groups. ${ }^{143}$

The House proceeded to pass the Committee's bill by an overwhelming vote, disregarding the objections of a few members and of the Administration on grounds of revenue inadequacy. ${ }^{144}$

The Senate hearings began with Morgenthau's testimony, on November 29. As soon as Morgenthau finished his prepared remarks, in which he renewed his request for $\$ 10.5$ billion in new revenue, Senator Arthur Vandenberg asked him whether he would prefer "a bill approximately similar to the House bill in total revenue, or the House bill plus a general sales tax." ${ }^{145}$ Morgenthau responded with the Administration's usual list of sales-tax objections and concluded, "For the above reasons, my answer to Senator Vandenberg's question is 'No.' We would prefer not having a sales tax." ${ }^{146}$ This prompted Senator Byrd to quote the last sentence of Morgenthau's prepared statement: "I have endeavored to show you as objectively and as clearly as I can that a tax program of not less than 10.5 billion dollars is needed to safeguard the financial and economic future of this country during the war and after the war." ${ }^{147}$ Senator Byrd then remarked,

That is pretty strong language. As I understand the Secretary, he thinks the objections to the sales tax are greater than the necessity of safeguarding the financial and economic future of the country, if the sales tax is determined by the committee and Congress as being the only means of raising this additional revenue. ${ }^{148}$

Morgenthau's position was not popular on the nation's editorial pages. The New York Times argued that a sales tax should be enacted to replace the Victory Tax as the mass tax:

The alternative [to the Victory Tax and the House bill's 3\% substitute tax] is not to exempt these groups completely. It is to reach them in a simpler way. That simpler way is through a general sales tax. But the Treasury, in spite of the fact that its arguments against a sales tax cannot hold under present circumstances, continues to oppose such a tax with undiminished vigor. It continues to object that a sales tax would put a disproportionate burden on low-income groups. The Treasury is still talking, in other words, as if that tax would be imposed in isolation.... If imposed instead of the proposed House substitute for the Victory tax, it would be the only substantial tax imposed on these low-income groups. Higher income groups, on the other hand, would have to pay both the sales tax and the income tax. ${ }^{149}$

143. Samuel B. Bledsoe, Boost in Taxes Waits on Election, N.Y. TIMES, Nov. 14, 1943, at E6.

144. Samuel B. Bledsoe, House Adopts Bill to Increase Taxes by $\$ 2,139,300,000$, N.Y. TIMES, Nov. 25,1943 , at 1 .

145. Hearings Before the Comm. on Finance on the Revenue Act of 1943, 78th Cong. 4 (1943).

146. Id. at 7 .

147. Id. at 14 .

148. Id.

149. Treasury and Sales Tax, N.Y. TIMES, Dec. 1, 1943, at 20. 
The Los Angeles Times followed with an editorial criticizing "the remarkably poor showing made against [a sales tax] by Mr. Morgenthau," and urging the Senate to pass a sales-tax bill. ${ }^{150}$

The Finance Committee, however, proved unwilling to recommend a sales tax over the Administration's objection. Instead, it reported a bill without a sales tax, and with almost the same revenue yield as the House bill- that is, more than $\$ 8$ billion short of the Treasury's request. ${ }^{151}$ Unlike the House bill, the Finance Committee's bill retained the Victory Tax in its existing form. ${ }^{152}$ The Senate passed the Committee's bill without major changes on January 20, 1944. ${ }^{153}$ The bill that emerged from the Conference Committee, which retained the Victory Tax but reduced its rate to $3 \%$, easily passed both the House and the Senate on February $7 . .^{154}$ President Roosevelt waited for almost two weeks, then vetoed the bill. ${ }^{155}$ In his veto message he described the bill as "wholly ineffective" as a revenue measure. ${ }^{156}$ Noting that the bill included "relief from existing taxes which would cost the Treasury at least $\$ 150,000,000$," the President declared, "[I]t is not a tax bill, but a tax relief bill providing relief not for the needy but for the greedy." ${ }^{\prime 157}$ Angry members of Congress voted overwhelmingly to override the veto; the vote to override was 299 to 95 in the House, and 72 to 14 in the Senate. ${ }^{158}$

With the passage of the Revenue Act of 1943 (in early 1944), revenue raising disappeared from the national political agenda for the remainder of the war; thus the debates of 1943 proved to be the last hurrah for proponents of a federal retail sales tax. In late May, the President signed the noncontroversial Individual Income Tax Act of 1944. ${ }^{159}$ This revenue-neutral legislation relabeled the Victory Tax the "normal tax" and reduced its exemption level from $\$ 624$ to $\$ 500$, while retaining the $3 \%$ rate. As had been the case with the Victory Tax, the exemption level of the normal tax was unaffected by marital status or the existence of dependents. For income-tax purposes other than the normal tax, the Act standardized exemptions at $\$ 500$ per person, for both taxpayers and dependents. ${ }^{160}$ The reduction of the Victory Tax (now the normal tax) exemption level from $\$ 624$ to $\$ 500$ made the income tax even more of a mass

150. The Muddled Mr. Morgenthau, L.A. TIMES, Dec. 9, 1943, at A4.

151. Samuel B. Bledsoe, George Replies to Morgenthau, N.Y. TiMES, Dec. 22, 1943, at 19.

152. Samuel B. Bledsoe, Senate Advances Its Own Tax Bill, N.Y. TIMES, Jan. 13, 1944, at 14.

153. Revised Tax Bill Passed by Senate, up to Conference, N.Y. TIMES, Jan. 21, 1944, at 1.

154. Samuel B. Bledsoe, Tax Bill Adopted, Congress Puts It up to Roosevelt, N.Y. TIMES, Feb. 8, 1944 , at 1 .

155. Franklin Delano Roosevelt, Tax Bill Veto Message, N.Y. TIMES, Feb. 23, 1944, at 14.

156. Id.

157. Id.

158. C.P. Trussell, Taxes Voted Law by 72-14 in the Senate, N.Y. TIMES, Feb. 26, 1944, at 1; Revenue Act of 1943, Pub. L. No. 78-235, 58 Stat. 21 (1944).

159. Simplified Tax Bill Signed by President, N.Y. TIMES, May 31, 1944, at 1; Individual Income Tax Act of 1944, Pub. L. No. 78-315, 58 Stat. 231.

160. Individual Income Tax Act of 1944, Pub. L. No. 78-315, §10(b), 58 Stat. 231, 238. 
tax; the percentage of the population covered by taxable returns rose from $68.9 \%$ in 1943 to $74.3 \%$ in $1944 .^{161}$

Outside of Congress, there was still substantial interest in a federal retail sales tax. Noting that taxes were financing less than half of the cost of the war, that the budget deficit was about $\$ 50$ billion, and that the threat of inflation had not abated, the New York Times editorialized, "A general retail sales tax, which would act as a check on consumption at the same time as it would increase Government revenues, seems the most desirable solution." ${ }^{162}$ In opinion polling, the public continued to support a federal retail sales tax. A March 1944 Gallup Poll found most respondents with an opinion would be willing to pay higher taxes to support the war effort (by a margin of $48 \%$ to $42 \%$ ), and a majority preferred a retail sales tax to an income-tax increase if taxes were to be raised (by a margin of $55 \%$ to $34 \%$ ). ${ }^{163}$

With eventual victory in the war now expected, proposals emerged for postwar changes in the federal tax structure. Industrialist Henry J. Kaiser advocated a postwar, federal retail sales tax of $10 \%$ for the purpose of liquidating the national debt. ${ }^{164}$ A group of Minnesota businessmen offered the "Twin Cities Plan" for postwar taxation; their plan featured a 5\% retail sales tax and a substantial increase in income-tax exemption levels, thus making the sales tax, rather than the income tax, the major instrument of federal mass taxation. ${ }^{165}$

Congress, however, never again came close to enacting a retail sales tax, either during or after the war. Faced with the massive national debt resulting from the war, Congress also never returned the income tax to its prewar status as a class tax. Appearing before the Ways and Means Committee in September 1945, shortly after the end of the war, Fred M. Vinson-President Truman's new Secretary of the Treasury-recommended a tax reduction of $\$ 5$ billion (to come into effect in 1946), but warned against larger cuts. ${ }^{166}$ Vinson told the Committee, "[F]irst, . . . expenditures cannot fall immediately to their eventual post-war level, and, second, ... when we do reach a post-war plateau it is bound to be far higher than the pre-war expenditure level." ${ }^{167}$ The two key features of Vinson's proposal were the repeal of the corporate excess-profits tax and the repeal of the normal tax. ${ }^{168}$ Vinson criticized the normal tax for applying "without regard to family status or number of dependents." 169 Treasury

161. SELTZER, supra note 1 , at 62 tbl.9.

162. Taxes-and Inflation, N.Y. TIMES, May 6, 1944, at 14.

163. George Gallup, Sales Tax in U.S. Backed by Public, N.Y. TIMES, Mar. 19, 1944, at 35.

164. Kaiser Urges Postwar Sales Tax to Pay Debt, L.A. TIMES, November 20, 1943, at 3.

165. Carl Shoup, Three Plans for Post War Taxation, 34 AM. ECON. REV. 757 (1944) (describing the Twin Cities Plan and two other proposals not involving federal sales taxes); C.P. Trussell, Post-War Tax Plan Is Offered to Encourage Private Enterprise, N.Y. TIMES, July 10, 1944, at 22.

166. Fred M. Vinson, Vinson's Proposals for Slashes in Taxes on Individuals and Corporations, N.Y.

TiMES, Oct. 2, 1945, at 14.

167. Id.

168. Id.

169. Id. 
estimated that repeal of the normal tax would remove twelve million taxpayers from the income-tax rolls. ${ }^{170}$

Few in Congress objected to Vinson's proposal to liberate twelve-million persons from the income tax. Chairman George of the Senate Finance Committee indicated he favored removing only three- to five-million persons from the income-tax lists, ${ }^{171}$ but he was unable to persuade even his own Committee. ${ }^{172}$ There were some rumblings from outside Congress about the proposal to decrease the scope of the income tax. The New York Times, for example, editorialized on the political significance of mass taxation: "[I]t is . . . important to have as wide an income tax as possible. It makes no difference whether the amount collected from those in the lower income brackets is a nominal sum. What is important is that the great majority of voters be kept aware at all times that they are making a contribution toward every dollar that the Federal Government spends." ${ }^{173}$ This view failed, however, to gain any traction in Congress.

For the most part, Congress gave Secretary Vinson what he had requested. The final bill cut taxes by almost $\$ 1$ billion more than Vinson had proposed; in addition to repealing the excess-profits tax and eliminating the income-tax liabilities of the twelve million persons who were subject to the income tax only because of the normal tax, it provided for corporate and individual income-taxrate reductions. ${ }^{174}$ Contrary to Vinson's request, the legislation did not nominally repeal the normal-tax label. Instead, it retained the normal tax but permitted taxpayers to claim normal-tax exemptions based on family size ( $\$ 500$ for each family member) in lieu of the prior rule allowing a normal-tax exemption of only $\$ 500$ regardless of family size. ${ }^{175}$ In addition, the legislation reduced the rate applicable to each bracket of the surtax (that is, the income tax other than the normal tax) by three percentage points. ${ }^{176}$ In substance, although not in name, the combination of these two changes accomplished the repeal of the normal tax. Despite the larger-than-requested revenue reduction, President

170. $I d$.

171. Senators Expected to Cut Tax Exempt, N.Y. TiMES, Oct. 15, 1945, at 3.

172. C.P. Trussell, Senators Sanction a Bigger Tax Slash for the Individual, N.Y. TIMES, Oct. 20, 1945 , at 1.

173. Taxes in a Democracy, N.Y. TIMES, Oct. 17, 1945, at 16. Arthur Krock, a New York Times columnist, took the same position. He claimed that "everyone who earns something should pay something [in taxes] if only because that brings the behavior of the government to his attention," and asked rhetorically, "[H]ow can taxes be fair among the people when more than twelve millions are ... released from them?" Arthur Krock, The Political Aspect of Tax Reduction, N.Y. TIMES, Oct. 5, 1945, at 22 .

174. John H. Crider, $\$ 5,920,000,000$ Cut in Taxes for 1946 Set by Conferees, N.Y. TIMES, Oct. 28, 1945, at 1; C.P. Trussell, Bill to Cut Taxes by $\$ 5,920,000,000$ Goes to President, N.Y. TIMES, Nov. 2 , 1945 , at 1 .

175. Revenue Act of 1945, Pub. L. No. 79-214, § 102(a), 59 Stat. 556, 558.

176. Revenue Act of 1945, Pub. L. No. 79-214, § 101(b), 59 Stat. 556, 557-58. 
Truman signed the bill without comment. ${ }^{177}$ With the introduction of normal-tax exemption levels based on family size, the percentage of the population covered by taxable income tax returns fell from $74.2 \%$ in 1945 to $55.8 \%$ in $1946 .{ }^{178}$

Congress did not raise income-tax-exemption levels again until 1948, and the increase then was modest-from $\$ 500$ for a single person, $\$ 1000$ for a married couple, and $\$ 500$ for each dependent, to $\$ 600, \$ 1200$, and $\$ 600$, respectively. ${ }^{179}$ Although inflation steadily decreased the real value of the income-tax exemptions, Congress did not increase exemption levels again until 1969. ${ }^{180}$ After reaching a postwar low of $54.3 \%$ in 1949 , the percentage of the population covered by taxable returns rose steadily thereafter, ${ }^{181}$ and the status of the income tax as a mass tax was never seriously threatened.

III

\section{IMAGINING THE POSTWAR FEDERAL TAX STRUCTURE IF THE ROOSEVELT ADMINISTRATION HAD NOT OPPOSED A WARTIME SALES TAX}

\section{A. Posing the Counterfactual Questions}

It seems reasonably clear that a federal retail sales tax would have been enacted during World War II, but for the intense and unwavering opposition of President Roosevelt and his Treasury Department. It also seems reasonably clear that the primary ground of that opposition-the claim that a retail sales tax would be uniquely oppressive to lower-income groups-was, to be charitable, less than wholly rational. ${ }^{182}$ As was pointed out repeatedly during the war by members of Congress, tax experts, and leading national newspapers, it would have been entirely feasible to adopt a sales tax with coupon-based exemptions, which would have been no more burdensome to lower-income groups than subjecting them to the income tax by lowering exemption levels. ${ }^{183}$

Apart from questions of distributional effects, reasonable minds could have differed on whether it would have been preferable to pursue mass taxation solely through the income tax, solely through the sales tax, or through both. As an instrument of mass taxation, each tax has its share of advantages and disadvantages. For example, the base of each tax is less than ideally

177. Reduced Tax Bill Signed by Truman, N.Y. TimES, Nov. 10, 1945, at 1; Revenue Act of 1945, Pub. L. No. 79-214, 59 Stat. 556.

178. SELTZER, supra note 1, at 62 tbl.9.

179. Revenue Act of 1948, Pub. L. No. 80-471, 62 Stat. 110.

180. Tax Reform Act of 1969, Pub. L. No. 91-172, 83 Stat. 487.

181. SELTZER, supra note 1, at 62 tbl.9.

182. More precisely, the primary ground of the opposition was less than wholly rational on the merits. It may be that opposing a sales tax made political sense for the Administration, given the hostility of organized labor to sales taxes. See Samuel B. Bledsoe, Boost in Taxes Waits on Election, N.Y. TimES, Nov. 14, 1943, at E6 ("Labor is strongly opposed to the sales levy and there are a lot of political hazards in the [sales-tax] proposal."). Under this view, however, the locus of irrationality merely shifts from the Administration to organized labor.

183. See, e.g., HARDY, supra note 104, at 27. 
comprehensive, but in different ways. The income tax largely fails (as a practical matter, albeit not as a theoretical matter) to tax self-employment income, while most retail sales taxes omit purchases of consumption services from the tax base. $^{184}$ (One response to the differing flaws in the bases of the two taxes would be that both taxes should be used, on the grounds that most dollars that escaped one tax would not escape the other.) As another example, the two taxes differ greatly in the way the ordinary person experiences their administration, but it is debatable which tax is superior in this respect. Is the sales tax preferable because it spares lower-income persons the hassle of preparing and filing tax returns, or is the income tax preferable because it confers symbolic taxpayer status-and thus fiscal citizenship-on lower-income persons in a way a sales tax cannot?

Turning from the taxpayer's perspective to the tax administrator's, would it be more difficult to put in place a massive new sales-tax-collection apparatus, or to put in place a massive new income-tax-withholding apparatus? That many states already had retail sales taxes had conflicting implications for a retail sales tax as an instrument of federal mass taxation. Did the existence of state retail sales taxes indicate that the federal government should also use a retail sales tax because a large portion of the country's population was already familiar with and accepting of retail sales taxes? Or did it indicate that the federal government should refrain, out of federalism concerns, from interfering with an established state revenue source?

After contemplating the pros and cons of the two types of mass taxation, one might reasonably favor using one tax, or the other, or both, for purposes of wartime mass taxation. Thus, the claim here is not that there necessarily should have been a wartime federal retail sales tax. Rather, the somewhat narrower claims are (1) that, given prevailing sentiments among the public and members of Congress, there would have been such a tax, but for the Administration's intransigence; (2) that the intransigence was based not on debatable secondorder claims about technical, symbolic, or administrative advantages of mass income taxation over mass sales taxation, but on first-order claims about fundamentally different distributional effects of the two types of taxes; and (3) that those first-order claims were wrong.

The story of the wartime sales-tax-that-wasn't suggests a question: How differently would the federal tax structure have developed in the more than six decades since the end of World War II if the Roosevelt Administration had not been so unalterably (and unreasonably) opposed to a wartime sales tax? There is a significant chance that, in the absence of the Administration's sales-tax opposition, there would not have been a mass income tax in postwar America. Rather, the postwar federal tax structure might have been a mass indirectconsumption tax (initially a retail sales tax, perhaps later changing to a VAT

184. See id. at 23-24 (noting that most wartime sales-tax proposals did not contemplate the taxation of sales of services). 
because of a VAT's administrative advantages), and a class-based income tax imposed on only the wealthiest 10 or $20 \%$ of the population. ${ }^{185}$

Political scientists recognize that public-policy developments are often highly path dependent. As Jacob Hacker observes, "Early policy choices [may] transform[] the menu of future options by pushing policy down self-reinforcing paths from which departure may be difficult." ${ }^{, 186}$ Hacker explains,

The concept of path dependence pushes... toward a greater appreciation of the alternative possibilities that exist in political history. We cease to conceive of policy outcomes as inevitably rooted in enduring characteristics of nations, whether they be institutions or ideas, structure or culture. If timing and sequence matter then we can often recognize different historical paths leading to very different destinations. ${ }^{187}$

An examination of how Roosevelt's opposition to a wartime sales tax shaped postwar federal tax policy is a case study in path dependence. As such, it is an exercise in counterfactual history. Counterfactual history has its pitfalls, and its excesses are easily mocked: consider Thurber's famous essay, "If Grant Had Been Drinking at Appomattox, ${ }^{188}$ or the old Saturday Night Live skit asking how World War II would have been different if Eleanor Roosevelt could have flown. But counterfactual history also has its uses, as long as the "what if" question is not silly, the answer is well-grounded in the available evidence, and the answer is presented in terms of possibilities and probabilities rather than certainties.

Counterfactual claims are much more common in historical analysis than is often recognized. Any time a historian claims that $X$ caused $Y$, she is making the counterfactual claim that $Y$ would not have happened if $X$ had not happened first. "Implicit in every causal assertion ... is a set of counterfactual implications." 189 Thus, the claim made earlier in this article, that the Roosevelt Administration's opposition to a wartime sales tax was the cause of Congress's failure to enact such a tax, is itself counterfactual history. The evidence in support of the causal claim is so strong, however, that the claim is not particularly speculative. One cannot assert with nearly the same level of confidence how the federal tax system might have developed following the war, had that development taken a wartime system with a sales tax as its starting point.

B. Postwar Mass Taxation in the Alternate Universe

Would there have been a mass income tax in the postwar decades if the Roosevelt Administration had not opposed a retail sales tax during World War II? Reasonable scenarios can be constructed in support of three different

185. In other words, we might have today a federal tax structure very similar to that proposed by Michael Graetz in his essay, 100 Million Unnecessary Returns. Michael J. Graetz, 100 Million Unnecessary Returns: A Fresh Start for the U.S. Tax System, 112 YALE L.J. 261 (2002).

186. JACOB S. HACKER, THE Divided WELFARE STATE 26 (2002).

187. Id. at 26-27.

188. JAmes Thurber, The Middle-Aged MAN ON THE Flying Trapeze 132 (1953).

189. Martin Bunzl, Counterfactual History: A User's Guide, 109 AM. Hist. REV. 845, 855 (2004). 
outcomes in the absence of the Administration's hostility to a wartime sales tax: (1) that the United States today would have a mass income tax and no federal sales tax (or VAT), (2) that the United States today would have both a federal sales tax (or VAT) and a mass income tax, and (3) that the United States today would have a federal sales tax (or VAT) and an income tax imposed on only the affluent minority of the population. The third outcome, although far from certain, is decidedly plausible. In other words, it is quite possible that the federal income tax would not be a mass income tax today had President Roosevelt not opposed a wartime sales tax. As an elaboration of this claim, consider two versions-both plausible, although they do not exhaust the universe of reasonable speculations - of what might have happened to postwar federal taxation if there had been a wartime sales tax. In the first version, there would be a mass income tax today — and no sales tax or VAT—regardless of the Roosevelt Administration's wartime position on the sales tax. In the second version, the Administration's opposition to a wartime sales tax is a but-for cause of today's mass income tax.

In the first version, everything plays out exactly as it actually did, except instead of enacting the Victory Tax in 1942 (effective in 1943), Congress enacts a retail sales tax with approximately the same revenue production and distributional effects as the actual Victory Tax. ${ }^{190}$ The plausibility of this version derives from the fact that Finance Committee Chairman George proposed the Victory Tax specifically in an attempt to ward off the enactment of a sales tax..$^{191}$ If George had not suggested the Victory Tax at the crucial moment, a sales tax might have been enacted in its place. If later events then developed just as they actually did, except for the sales tax appearing in place of the Victory Tax, then there would have been a postwar mass income tax despite the enactment of the wartime sales tax.

In this version, the exemption levels of the regular income tax (that is, the income tax apart from the Victory Tax-normal tax) would have been reduced during the war exactly as much as they were actually reduced. Instead of Congress's repealing (de facto) the Victory Tax-normal tax in late 1945, it would have repealed the sales tax. And just as the income tax still covered a majority of the population $\left(55.8 \%{ }^{192}\right)$ in 1946 after the repeal of the Victory Tax-normal tax, it would have covered a majority of the population in 1946 after repeal of the sales tax. With the sales tax repealed and the income tax in exactly the same position in 1946 that it occupied in the actual history, the post1946 alternate history of the income tax would have been the same as its actual

190. Of course, just as an income tax need not feature the Victory Tax's insensitivity to taxpayers' family responsibilities, a retail sales tax with a coupon-based exemption need not ignore family responsibilities. Wartime proposals for retail sales taxes often included exemptions that were larger for families than for individuals. See, e.g., HARDY, supra note 104, at 27 (suggesting an exemption of \$200 for a single person and $\$ 350$ for a family), and STATEMENT OF THE DIVISION OF TAX RESEARCH, supra note 129, at 1164-65 (discussing, but not endorsing, the idea of a per capita exemption of \$150).

191. See Trussell, supra note 87 and accompanying text.

192. SELTZER, supra note 1 , at 62 tbl.9. 
history. Under this version, then, the absence of a federal retail sales tax during World War II had no lasting effect on the structure of federal taxation. We would have a mass income tax and no sales tax today even if Senator George had not proposed the Victory Tax.

The careful reader, however, may have noticed a problem with the above version. It is a plausible story of how there might have been a retail sales tax during World War II without the effects of that tax enduring to the present. It is not, however, a story about how federal taxation might have developed but for the Roosevelt Administration's resistance to a sales tax. Rather, it is a story about what might have happened if Congress had enacted a sales tax over the Administration's opposition.

At war's end, the Victory Tax-normal tax, with its rate reduced from the original $5 \%$ to $3 \%$, was raising only about $\$ 2$ billion per year. ${ }^{193}$ Although a sales tax enacted over the Administration's opposition might have had a similarly modest revenue yield, if the Administration had been supportive of a sales tax (or even neutral), the revenue yield might have been much higher. The Brookings Institution's 1943 proposal, for example, was for a sales tax that would have raised about $\$ 5$ billion per year (if imposed on the 1941 economy), either by a $10 \%$ tax without exemptions or by a $13 \%$ tax with a $\$ 200$ exemption for single persons and a $\$ 350$ exemption for families. ${ }^{194}$ Despite its steadfast opposition to a sales tax, the Treasury Department in October 1943 provided the Ways and Means Committee with a revenue estimate for a $10 \%$ sales tax without exemptions - $\$ 6.3$ billion, under economic conditions forecast for 1944. ${ }^{195}$ Later that month, Ways and Means voted down a proposal for a $10 \%$ retail sales tax with a $\$ 400$ exemption for the average family, ${ }^{196}$ but of course that vote was taken in the shadow of the Administration's hostility to a sales tax.

All this suggests a second version of how events might have played out if the Roosevelt Administration had not objected to a retail sales tax. But for the Administration's unyielding opposition, during World War II Congress might have enacted a sales tax with a rate in the range of $10 \%$ to $15 \%$, and with an annual revenue yield (by the end of the war) of $\$ 5$ billion or more. With so productive a sales tax, Congress might never have extended the coverage of the income tax to a majority of the population. Congress certainly could have kept income tax exemption levels high enough to excuse the bulk of the population from the income tax and still have raised as much wartime revenue as it actually

193. C.P. Trussell, Five Billion Tax Reduction, Exempting 12,000,000 Payers, Urged on Congress by Vinson, N.Y. TIMES, Oct. 2, 1945, at 1 (reporting Treasury's estimate that repeal of the normal tax would reduce tax receipts by $\$ 2,085,000,000)$.

194. HARDY, supra note 104, at 23-29.

195. TREASURY DEP'T, STATEMENT OF THE DIVISION OF TAX RESEARCH, supra note 129, at $1150-51$.

196. Samuel R. Bledsoe, Sales Tax Beaten in Committee, 16-8, N.Y. TIMES, Oct. 29, 1943. 
did, if it had enacted a retail sales tax producing $\$ 5$ billion or more. ${ }^{197}$ Whether it would have done so is impossible to say. Recall that the Revenue Act of 1943 fell about $\$ 8$ billion short of the Administration's request, largely because of the impasse between the Administration and Congress over a retail sales tax. ${ }^{198}$ Without that impasse, it is possible that Congress would have financed the war more through taxation and less through borrowing; thus the increased revenue produced by a sales tax (in comparison with the Victory Tax-normal tax) would not necessarily have resulted in a dollar-for-dollar decrease in income-tax revenues. On the other hand, there is also considerable evidence that Congress simply grew weary of revenue raising by the middle of the war. And that suggests that Congress might have been unwilling to satisfy the Administration's revenue request quite apart from the sales-tax controversy. Under this interpretation, it is plausible that sales-tax revenues would have reduced income-tax revenues dollar-for-dollar.

Suppose, then, that in late 1945 there was a sales tax producing $\$ 5$ billion or more in annual revenue and an income tax with relatively high exemption levels, which covered significantly less than half the population. If Congress and the Truman Administration had then agreed on the propriety of a tax cut of $\$ 5$ or $\$ 6$ billion, what form might the cut have taken? It is not unimaginable that Congress would have devoted the entire tax cut to the repeal of the sales tax. The numbers would have worked out rather neatly, and many proponents of a federal sales tax had stated that their support was limited to the wartime emergency. ${ }^{199}$ On the other hand, that would have left no money for repealing (or even reducing) the excess-profits tax (a tax that made little sense outside of wartime) or for providing any relief for income taxpayers (either in the form of rate reductions or increased exemption levels). Moreover, it would have left the federal tax structure with no general-revenue tax directly affecting a majority of the population. ${ }^{200}$ All of these results seem politically improbable. A more likely result would have been the repeal of the excess-profits tax (at a revenue cost of about $\$ 2.6$ billion $^{201}$ ), with the remainder of the tax cuts divided between the retail sales tax and the individual income tax-including, perhaps, an increase in income-tax-exemption levels, moving the income tax even farther away from mass-tax status.

If, in this alternate universe, income tax exemption levels were raised in 1948 (as they were in the actual universe), the federal tax structure in the late

197. Even with the actual wartime reductions in exemption levels (for purposes other than the Victory Tax-normal tax), the income tax in 1946 covered only a slight majority of the population $(55.8 \%)$. SELTZER, supra note 1 , at 62 tbl.9. Exemption levels only modestly higher would have been sufficient to exclude a majority of the population from the coverage of the income tax.

198. See supra text accompanying notes 120-60 (describing the events leading to the enactment of the Revenue Act of 1943).

199. See, e.g., The Sales Tax Looms, WASH. Post, Jan. 10, 1942, at X8.

200. The Social Security tax directly affected all families with wage earners, but it was not, of course, a tax for general revenue purposes.

201. Trussell, supra note 193. 
1940s might have very closely resembled that recently proposed by Michael Graetz: a mass indirect consumption tax (retail sales tax in the alternate universe, a VAT under Graetz's proposal) and an income tax applicable to only an affluent minority of the population (those with incomes greater than $\$ 100,000$, under Graetz's proposal). ${ }^{202}$ Would the system have been stable in the subsequent decades, or would the income tax have eventually become a mass tax even in the alternate universe? The system might well have endured, for the same reason Graetz suggests that his proposed system, once enacted, would resist erosion:

[R]eduction of the $\$ 100,000$ income tax exemption seems extremely unlikely. A political speech urging restoration of income taxation to families with incomes below that level is difficult to imagine, regardless of the speaker's political party. Remember, it took the cataclysm of World War II to extend the income tax to the masses in the first instance. ${ }^{203}$

To belabor the obvious, all of this is speculation. I hope to have persuaded the reader that it is plausible that a retail sales tax or a VAT, rather than the income tax, would be the only federal instrument of general-revenue mass taxation today, but for the Roosevelt Administration's implacable and notfully-rational wartime opposition to a sales tax. In particular, I hope readers find that outcome sufficiently likely to pique their interest in the following speculations about the likely collateral consequences to the United States-for everything from health care, to pensions, to housing, to antipoverty programsof having emerged from World War II with the income tax, rather than a sales tax, as its method of mass taxation.

\section{IV}

\section{DIFFERENCES BETWEEN THE ACTUAL POSTWAR DEVELOPMENT OF THE MASS INCOME TAX AND THE LIKELY POSTWAR DEVELOPMENT OF A TWO-TAX SYSTEM}

Suppose, at a particular point in time, a country is deciding between two tax systems-(1) a mass income tax, or (2) a retail sales tax (or VAT) and a class income tax-each of which will feature the same initial distribution of tax burdens. In the years following the country's choice, what are the likely ramifications of that choice? When the question is posed that broadly, its significance is not limited to the long-term consequences of the Roosevelt Administration's wartime position on the sales tax. The broader question is also significant in deciding whether the United States should retain the mass income tax today or adopt a two-tax structure along the lines proposed by Michael Graetz.

202. Graetz, supra note 185 .

203. Id. at 301. 
A. The Effect of a Two-Tax System on the Politics of Tax Cuts and Tax Increases

Suppose the United States had emerged from World War II with a two-tax system (a retail sales tax and a class income tax) that was distributionally identical to the actual postwar mass income tax. As congressional revenue objectives increased and decreased over the subsequent decades, would the distributional effects of tax hikes and tax cuts have been different under a twotax system than under the actual single-tax system? To pose the question a bit more generally, assuming Congress has decided to raise or lower revenues by a given amount, is Congress likely to distribute the burdens or benefits differently if it is working with a retail sales tax (or VAT) and a class income tax than if it is working with only a mass income tax?

Edward J. McCaffery and Jonathan Baron conducted a series of experiments on the Internet, in which they asked subjects for their views on the fair distribution of tax burdens under a two-part federal tax structureconsisting of a mass income tax and a mass payroll tax-under a variety of "framing manipulations." ${ }^{204}$ Not surprisingly, they found,

When people are asked to adjust a tax so that they approve of the total tax system .... they do not use the tax they can change to compensate for what they see as undesirable features of some other tax. Subjects seem instead simply to focus on what they are asked to judge.

In other words, people tend to judge the fairness of each tax in isolation, rather than to judge the fairness of the overall effects of the tax system. This disregard of one tax in adjusting the other is not absolute, however. McCaffery and Baron found that subjects were "insufficiently sensitive" to the undesirable features of the other tax, not completely insensitive. ${ }^{206}$ "[I]ndeed, [people] are influenced somewhat by the other tax," they report. ${ }^{207}$ It seems clear from the McCaffery-Baron study that the political dynamics of tax hikes and tax cuts under a tax structure consisting of a retail sales tax (or VAT) and a class income tax would be different from the political dynamics under a solitary mass income tax; to some considerable extent, the distributional merits of each tax would be judged independently of the other tax. There is good reason to suppose, then, that the resulting tax increases or decreases would not be the same as under a stand-alone income tax. Thus, even if the combination of a retail sales tax and a class income tax had started the postwar era with the same distributional impact

204. Edward J. McCaffery \& Jonathan Baron, The Humpty Dumpty Blues: Disaggregation Bias in the Evaluation of Tax Systems, 91 ORG. BEHAV. \& HuM. DECISION PROC. 230, 233 (2003) ("We define a framing manipulation as a formal presentation where the relevant information is held constant across two or more modes of description or presentation."). A significant difference between the taxes in their experiments, and the combination of a retail sales tax (or VAT) and a class income tax, is that both of their taxes are mass taxes. Id. at 234.

205. Id. at 241.

206. Id. at 236 .

207. Id. at 241 . 
as the actual postwar mass income tax, in subsequent decades the distributional effects in the alternate universe would have diverged from the actual distributional impacts of the mass income tax.

Although the distributional results would surely have been different under a two-tax system, the nature or extent of the differences is far from clear. Informed speculation is possible, however, and some is offered here. The assumption in the musings that follow is that the disaggregation bias is substantial, but far from absolute. That is, distributional arguments viewing each tax in isolation would have had considerable impact, but distributional arguments viewing the two taxes together would also have had some force.

With respect to tax cuts, a two-tax system would probably have produced results more favorable to the masses than the various actual income-tax cuts since World War II. The politically dominant paradigm for the distribution of income tax cuts has been that a cut is distributionally neutral if it reduces all taxpayers' income-tax liabilities by the same percentage. This view was clearly expressed by President Reagan in a 1981 speech celebrating the recently enacted Economic Recovery Act of 1981: ${ }^{208}$

Now, of course, those having a larger tax will get a larger reduction in the number of dollars. The fellow paying a $\$ 10,000$ tax will get a $\$ 1,000$ reduction. The fellow paying a $\$ 1,000$ tax will get $\$ 100$ off. But the first one will still be paying 10 times as much as the other one. The tax rate reduction is the same percentage across the board. ${ }^{209}$

More recently, the Treasury Department under President George W. Bush implicitly adopted the same paradigm in its distributional analyses of the 2001 and 2003 tax cuts. ${ }^{210}$ The Treasury's analyses focused on the percentage decreases in individual income-tax liabilities for taxpayers in various income categories. ${ }^{211}$ Because the percentage decreases were generally smaller at higher income levels (significantly so in the case of the 2001 Act and slightly so in the case of the 2003 Act), the Treasury was able to claim that the tax cuts were progressive:

Because the percentage reduction in income taxes is greatest for families with incomes under $\$ 50,000$, these families will pay a smaller share of the total income tax burden than they do under current law. ... Conversely, families with incomes of $\$ 100,000$ or more receive a smaller than average reduction in income taxes so they will pay a larger share of the total income tax than they do under current law. ${ }^{212}$

208. Economic Recovery Act of 1981, Pub. L. No. 97-34, 95 Stat. 172.

209. Ronald Reagan, Excerpts from Reagan Talk to Carpenters' Union, N.Y. TIMES, Sept. 4, 1981, at A10.

210. Economic Growth and Tax Relief Reconciliation Act of 2001, Pub. L. No. 107-16, 115 Stat. 38; Jobs and Growth Tax Relief Act of 2003, Pub. L. No. 108-27, 117 Stat. 764.

211. Press Release PO-79, U.S. Dep't of The Treasury, Office of Public Affairs, Treasury Releases Distribution Table for the President's Tax Relief Plan (Mar. 8, 2001), reprinted in 2001 TAX NOTES TODAY 47-19 (Mar. 9, 2001); Press Release JS-409, U.S. Dep't Of The Treasury, Office Of Public Affairs, Treasury Releases Distribution Table for the Jobs and Growth Tax Relief Reconciliation Act of 2003 (May 22, 2003).

212. Press Release JS-409, U.S. Dep't of The Treasury, Office of Public Affairs, Treasury Releases Distribution Table for the Jobs and Growth Tax Relief Reconciliation Act of 2003 (May 22, 2003). 
As the tax cuts of 1981, 2001, and 2003 demonstrate, this paradigm for evaluating the distributional effects of tax reductions has been politically successful, despite the fact that tax cuts that are neutral under this paradigm would be skewed in favor of higher-income taxpayers under plausible alternative paradigms - in particular, under a paradigm focused on percentage increases in after-tax incomes at various income levels and under one focused on average dollars of tax reduction per taxpayer at various income levels. ${ }^{213}$

It seems unlikely that the equal-percentage-reduction paradigm would have the same level of intuitive appeal it apparently has under the mass income tax, if it were proposed to be applied to aggregate tax reductions under a two-tax system. McCaffery and Baron suggest that the most likely explanation for the disaggregation bias they identify is a "heuristic account": "[People] simply think about the fairness of the tax they are adjusting [rather than of the overall system], as a matter of habit." 214 Thus, the distributional outcomes of tax-cut debates would depend on the outcomes of preliminary debates over what was to be reduced-the sales tax, the income tax, or both. Although a tax-cut debate could, of course, be framed as a question of how much to decrease the combined burdens of the two taxes at various income levels, advocates of different income classes would attempt to frame the debate solely in terms of a reduction of one tax or the other. Advocates of the upper classes would be at a disadvantage in these preliminary debates, because a reduction in the retail sales tax would benefit the entire population, whereas an income-tax cut would benefit only the affluent minority.

One likely scenario would be a simple reduction in the single rate of the retail sales tax (or VAT). This has an elegant simplicity and would obviously be attractive to the extent the public could be persuaded to focus on the retail sales tax rather than on the aggregate effect of the two taxes. Moreover, the effects of such a reduction would be easy to defend, even from an aggregate perspective. It would be difficult for high-income taxpayers to complain that the approach was unfair to them when they would receive the largest tax reductions in dollar terms (assuming higher-income persons were also higher-consumption persons). This approach would, of course, be much less favorable to higherincome taxpayers than the equal-percentage-reduction approach that has dominated under the mass income tax. Imagine, for example, a 10\% (not tenpercentage-point) reduction in the rate of the retail sales tax. For the bulk of taxpayers who are subject only to the retail sales tax, this would mean a $10 \%$ reduction in their combined retail sales tax-income tax burden. But for an affluent taxpayer whose pre-reduction tax burden came $90 \%$ from the income tax and only $10 \%$ from the sales tax, this would mean only a $1.0 \%$ reduction in combined tax burden.

213. Lawrence Zelenak, Framing the Distributional Effects of the Bush Tax Cuts, 105 TAX NOTES $83,85-87$ (2004).

214. McCaffery \& Baron, supra note 204, at 241. 
An additional reason to suspect tax cuts under a two-tax system would be more favorable to lower-income taxpayers than tax cuts under the mass income tax is supplied by Larry Bartels' research on public attitudes to the 2001 tax cut. ${ }^{215}$ Bartels found that most people form their views on tax policy largely "on the basis of simple-minded and sometimes misguided considerations of selfinterest." 216 His analysis suggests that a taxpayer who believes his own tax burden is too high will support any package of income tax cuts, no matter how heavily skewed in favor of the rich, as long as the package includes some small reduction in the taxpayer's own tax bill. ${ }^{217}$ This raises the question whether the same dynamic would apply under a two-tax system or whether the result depends on the existence of a single mass tax. To ask the question using numbers based on the combined distributional effect of the 2001 and 2003 tax reductions: Would the public be willing to accept an average tax cut of $\$ 28,187$ for persons in the top $1.0 \%$ of the income distribution, and of $\$ 149,516$ for persons in the top $0.1 \%$, while persons in the bottom $80 \%$ receive an average cut of only $\$ 499$, if the large tax cuts for the rich are produced almost entirely by income tax reductions and the small cuts for the masses are produced by reductions in the sales tax (or VAT) $?^{218}$ It is very possible the public would not be willing to accept those distributional results under a two-tax system. The phenomenon described by Bartels depends on taxpayers of modest means viewing their tax cuts and those of the rich as parts of the same package, and they might be much less inclined to do so if their small tax reduction and the large tax reduction for the rich come from changes in two formally distinct taxes.

The analysis of how the politics of tax increases might change under a twotax system is more complicated than the tax-cut analysis because tax-increase legislation in the postwar era has not hewed to a consistent distributional paradigm. One paradigm is the mirror image of that for tax cuts. Under this approach, a distributionally neutral tax increase is one that raises every taxpayer's tax bill by the same percentage. This paradigm is illustrated by the temporary income tax surcharges enacted in 1968 and $1969 .{ }^{219}$ The 1968 surcharge simply increased each taxpayer's liability by $10 \%$, and the 1969 surcharge was an across-the-board increase of 5\%. As explained above, applying the equal-percentage paradigm in the case of tax cuts favors the rich. Applying the equal-percentage paradigm in the case of tax increases, however, produces a mirror image of the application to tax cuts; the equal-percentage paradigm applied to increases disfavors the rich. The other politically successful

215. Larry M. Bartels, Homer Gets a Tax Cut: Inequality and Public Policy in the American Mind, 3 PERSP. ON POL. 15 (2005).

216. Id. at 21.

217. Id. at 21-23.

218. For the dollar figures, see Tax Policy Center, tbl.04-0009, Mar. 18, 2004, available at http://www.taxpolicycenter.org. (\$499 is the author's calculation, based on Table 04-0009.)

219. Revenue and Expenditure Control Act of 1968, Pub. L. No. 90-364, 82 Stat. 251; Tax Reform Act of 1969, Pub. L. No. 91-172, 83 Stat. 487. 
paradigm for distributing income tax increases has been even tougher on the rich. Under this paradigm - which is reflected in the tax provisions of both the Omnibus Budget Reconciliation Act of 1990 and the Omnibus Budget Reconciliation Act of 1993-all or nearly all of the burden of tax increases is imposed on high-income taxpayers. ${ }^{220}$

How might the politics of distributing tax increases change under a two-tax system? A two-tax system would provide a very simple means of imposing the entire burden of a tax increase on the affluent-that is, raising income tax rates while leaving the mass consumption tax unchanged. Because that approach would also serve the self-interest of the bulk of the population, it might well have been followed in the alternate postwar universe. If so, the distribution of tax increases under the two-tax system would not have been terribly different from the actual results under the mass income tax. High-income taxpayers would have fared only modestly worse in 1968 and 1969, and the distributional results in 1990 and 1993 would have been roughly the same as the actual results. On the other hand, it is possible that the "soak the rich" character of obtaining the entire revenue increase from the income tax would have been a little too obvious under a two-tax system. Perhaps increasing the class tax while leaving the mass tax unchanged would be perceived as unfair, even by those who would benefit from that approach. If so, the two-tax system might have resulted in imposing less of the burden of tax increases on high-income taxpayers than actually occurred under the mass income tax.

There is only one certainty here: that the political dynamics of tax cuts and tax increases under a two-tax system would have been quite different from the actual dynamics under the mass income tax. Thus, there is no reason to suppose that the distribution of the federal tax burden would be the same today if the United States had had a two-tax system throughout the postwar era, even on the assumption that a two-tax system at the end of World War II would have had distributional effects identical to those of the actual mass income tax at war's end. To confidently assert anything more regarding distributional effects is impossible. It is likely, however, that postwar tax cuts under a two-tax system would have been less favorable to higher-income taxpayers than actual cuts have been. Postwar tax increases under the two-tax system might well have

220. Omnibus Budget Reconciliation Act of 1990, Pub. L. No. 101-508, 104 Stat. 1388; Omnibus Budget Reconciliation Act of 1993, Pub. L. No. 103-66, 107 Stat. 312. The 1990 Act slightly decreased the federal tax burdens on taxpayers with incomes below $\$ 20,000$, produced increased tax burdens ranging from a low of $1.5 \%$ to a high of $2.3 \%$ for taxpayers in various income ranges from $\$ 20,000$ to $\$ 200,000$, and increased the tax burdens of taxpayers with incomes above $\$ 200,000$ by $6.3 \%$. J. COMM. ON TAXATION, SUMMARY OF Distributional EFFECTS, By INCOME CATEGORY-BUdGeT RECONCILIATION (H.R. 5835)—REVENUE PROVISIONS AS REPORTED BY THE CONFEREES (JCX-4690 , Oct. 26, 1990). In the case of the 1993 Act, $100.9 \%$ of the net tax increase was imposed on the top quintile of the income distribution (including $94.6 \%$ on the top $10 \%$, and $76.3 \%$ on the top $1 \%$ ). CONG. Budget OfFice, An ECONOMIC ANALYSis of the REVENUE PROVISIONS OF OBRA-93, at 32 tbl.6 (Jan. 1994). Tax decreases (from the expansion of the earned income tax credit) for the two lowest quintiles of the income distribution made it possible for the increased tax imposed on the top quintile to exceed the Act's net tax increase. 
resembled actual increases or might even have been more favorable to highincome taxpayers than actual increases have been.

B. The Virtues and Vices of a Mass Income Tax with a Tax-Return Filing Requirement

Public attitudes to federal taxation and federal spending in the postwar era have been powerfully influenced by the fact that most American adults are required to file annual income tax returns. ${ }^{221}$ There are obvious objections to a mass return-filing requirement. The value of taxpayer time spent on return preparation in 2004 has been estimated at $\$ 70$ billion. ${ }^{22}$ Adding to that figure $\$ 15$ billion for professional assistance and other out-of-pocket return preparation costs, the total income-tax-compliance burden in 2004 was about $\$ 85$ billion-even without taking into account whatever "psychic" costs return preparation imposes on taxpayers. ${ }^{223}$ Michael Graetz considers the elimination of the filing requirement for most Americans to be the major selling point for his proposal to introduce a federal VAT and restore the income tax to its prewar status as a class tax-so much so that he features that selling point in the title of his article, "100 Million Unnecessary Returns." 224

A mass filing requirement, however, has two underappreciated virtues. First, return-based mass taxation combined with wage withholding constitutes a reasonable compromise between advocates of big government and advocates of small government on the level of visibility and painfulness of the tax system. ${ }^{225}$ The former would prefer the tax system to have the lowest possible visibility, on the assumption that the public will accept heavier burdens under a hidden tax than under an obvious tax. From this perspective, the ideal tax might be a VAT (built into the price of goods rather than separately stated), or a payroll tax nominally imposed on employers rather than employees. For mirror-image reasons, advocates of small government would prefer taxes to be as obvious and as painful as possible; their ideal tax might be a return-based income tax without wage withholding. A return-based income tax with inexact withholding splits the difference between the two camps.

Second, "the filing of a tax return can serve an important ceremonial function as an expression of fiscal citizenship. ${ }^{\$ 226}$ When Americans rhetorically claim taxpayer status to establish their right to participate in political discourse, it is overwhelmingly their status as return-filing income taxpayers to which they appeal. Although persons subject only to a retail sales tax or VAT would

221. Lawrence Zelenak, Justice Holmes, Ralph Kramden, and the Civic Virtues of a Tax Return Filing Requirement, 61 TAX L. REV. 53 (2007).

222. Joel Slemrod \& Jon BAKiJa, TAXing Ourselves: A Citizen's Guide to the Great DEBATE OVER TAX REFORM 161 (4th ed. 2008) (valuing taxpayers' time at $\$ 20$ per hour).

223. Id.

224. Graetz, supra note 185.

225. Zelenak, supra note 221, at 57-58.

226. Id. at 56 . 
certainly bear economic burdens of taxation, their taxpayer status-in their own minds and in the minds of others-would be much less perspicuous than it is today. In the alternate postwar tax universe, the mass of taxpayers subject only to the retail sales tax might have been widely perceived as second-class citizens, with less right to participate in the political process than the affluent minority subject to the income tax.

For present purposes, there is no need to decide whether the virtues of a widespread return-filing requirement outweigh the vices. The point is simply that the presence or absence of such a requirement is itself significant-in terms of compliance burdens, public attitudes toward federal finances, and political participation. Thus, the absence of a mass filing requirement in the alternate postwar tax system would have been enough to make the system importantly different from the actual system, even assuming no difference in the distributions of tax burdens under the actual and hypothetical systems.

\title{
C. The Proliferation of Nonbusiness Deductions and Credits
}

Writing in 2002, Michael Graetz complained,

\begin{abstract}
In the past decade, the President and Congress have used the income tax the way my mother employed chicken soup: as a magic elixir to solve all the nation's economic and social difficulties. If the nation has a problem in access to education, child care affordability, health insurance coverage, or the financing of long-term care, an income tax deduction or credit is the answer.
\end{abstract}

Graetz offered a convincing explanation for legislators' preference for this approach: "Republicans in Congress have never seen a tax cut they will not embrace, and Democrats now view income tax benefits as the best way to achieve domestic policy goals blocked by political barriers or legal limitations on additional spending." ${ }^{228}$ Congress's enthusiasm for tax-benefits-as-chickensoup has not waned in the years since Graetz's article appeared. Congress has added tax benefits (primarily in the form of credits) for, among other things, "nonbusiness energy property," "residential energy-efficient property," "alternative motor vehicles," medical insurance for certain displaced workers and retirees, "first-time homebuyers," and "health savings accounts."229

Graetz predicted that tax benefits of this sort would lose their appeal to Congress if Congress were to adopt his proposal to apply the income tax only to persons with incomes above $\$ 100,000$ and to replace the lost revenue with a VAT: "[T] he political impetus for festooning the tax code with tax breaks for specified expenditures... would disappear since such income tax allowances would offer no benefits to the vast majority of Americans." ${ }^{230}$ For the same reason, it is likely that the income tax would never have been festooned with

227. Graetz, supra note 185 , at 274 . He cites as examples, I.R.C. $\S \S 530$ (education), $45 \mathrm{~F}$ and 501(k) (childcare), 220 (health insurance), and 7702B (long-term care). Id. at 274 n.64.

228. Id. at 275 .

229. The statutory provisions are, respectively, I.R.C. $\S \S 25 \mathrm{C}, 25 \mathrm{D}, 30 \mathrm{~B}, 35,36$, and 223.

230. Graetz, supra note 185, at 297. 
such tax breaks if the income tax had never become a mass tax. The absence of such provisions in the pre-World War II class income tax supports this conclusion.

Of course, even in the absence of a mass income tax, Congress might have enacted direct-spending programs substantively equivalent to many of these tax breaks. Instead of enacting a tax credit for purchasers of hybrid cars ${ }^{231}$ for example, Congress might simply have provided for the issuance of government checks to hybrid purchasers. The question, however, is not whether Congress could have done so, but whether it would have. For two reasons, it almost certainly would not have enacted nontax equivalents of the tax benefits actually enacted, at least in the vast majority of instances.

The first of those reasons is suggested by Graetz's comment that "Republicans... have never seen a tax cut they will not embrace." In the absence of a mass income tax, equivalent programs would have had to take the form of spending increases, rather than tax cuts. Although drawing a policy distinction between an income-tax credit and an economically identical transfer program flies in the face of the notion that a dollar is a dollar is a dollar, there is good reason to suppose that a great many legislators would draw precisely that distinction. The view that there is a fundamental moral distinction between a dollar of tax reduction (good) and a dollar of transfer payment (bad) follows from the widely held belief in "everyday libertarianism," identified (disapprovingly) by Liam Murphy and Thomas Nagel. ${ }^{232}$ Everyday libertarianism is the belief that the pretax distribution of income is presumptively fair, so that the government bears a heavy burden of justification when it uses either taxes or transfer payments to alter that pretax distribution. Assuming Congress in the alternate postwar universe (with a retail sales tax and a class income tax, instead of a mass income tax) would have been as much in thrall to everyday libertarianism as the actual Congress appears to be, the hypothetical Congress would not have enacted nontax equivalents to the credits and deductions of which Congress has been so fond in recent years.

In addition to the philosophical barrier to such nontax equivalents, there would have been a practical barrier. A mass income tax provides a convenient delivery mechanism for a subsidy for, say, hybrid cars. In the absence of a mass income tax, Congress would have had to find or create some other subsidydelivering mechanism, and the expense and trouble of doing so might have dissuaded Congress from enacting the subsidy-in the unlikely event that it had not already been dissuaded by everyday libertarianism.

231. I.R.C. $§ 30 B(2005)$.

232. Liam Murphy \& Thomas NAgel, The Myth of OWNership: TAXes And Justice 31-37 (2002). See also Lawrence Zelenak, The Myth of Pretax Income, 101 MICH. L. REV. 2261 (2003) (book review). 


\section{The Earned Income Tax Credit}

The earned income tax credit (EITC) uses the income tax as the delivery mechanism for wage subsidies for low-income workers and their families. ${ }^{233}$ In 2009 , the EITC can be as large as $\$ 5657$, for a wage earner with three or more "qualifying children." ${ }^{234}$ In the phase-in range of the credit, the amount of the credit increases with the amount of earned income. ${ }^{235}$ At higher income levels, the credit is phased out. ${ }^{236}$ Unlike most personal-income-tax credits, the EITC is refundable; if the amount of the credit exceeds the claimant's precredit income tax liability, the claimant receives a check from the Treasury in the amount of the excess. In recent years, slightly more than ten percent of the aggregate amount of EITC dollars has served to offset precredit income-tax liabilities; the remainder has taken the form of transfer payments. In fiscal year 2008, for example, EITCs as tax liability offsets totaled $\$ 5.4$ billion, while EITCs as transfer payments totaled $\$ 45.3$ billion. ${ }^{237}$ With total benefits in excess of $\$ 50$ billion (in fiscal year 2008), the EITC is easily the largest federal antipoverty transfer program. An eligible taxpayer claims the EITC on his or her incometax return; no encounter with a welfare bureaucracy is required. The tax-based administration of the program contrasts sharply with the welfare-based administration of Food Stamps and Temporary Assistance for Needy Families (TANF).$^{238}$ As a consequence of this difference in administration, the EITC has much lower administrative costs than welfare-based programs, a much higher participation rate by eligible persons, and a much higher rate of overpayments. ${ }^{239}$

Something similar to the EITC - in terms of both substantive design and manner of administration - could be achieved, as a technical matter, without requiring EITC recipients to file income-tax returns. Indeed, in his proposal to eliminate the income-tax-return filing requirement for persons with incomes below $\$ 100,000$ (and to replace the lost revenue through the introduction of a VAT), Michael Graetz suggests, "Providing low-income workers tax offsets through the payroll-tax withholding system would allow elimination of the tax return filing requirement for these workers without increasing their taxes or eliminating their wage subsidy." ${ }^{240}$ Under this approach, a low-wage worker would receive, in lieu of the EITC, a wage subsidy in the form of a downward adjustment in the amount of her wages withheld under the Social Security (and

233. I.R.C. $\$ 32(2009)$.

234. Rev. Proc. 2009-21, 2009 IRB LEXIS 147, \$4 (2009).

235. I.R.C. § 32(a)(1) (2009).

236. I.R.C. § 32(a)(2) (2009).

237. OfFice of MgMt. \& Budget, Exec. OfFice of the President, Budget of THE United STATES GOVERNMENT, FISCAL YEAR 2008: ANALYTICAL PERSPECTIVES 289-90 (2007).

238. For a detailed description of the differences between tax-based administration of the EITC and welfare-based administration of Food Stamps and TANF, see Lawrence Zelenak, Tax or Welfare: The Administration of the Earned Income Tax Credit, 52 UCLA L. REV. 1867, 1876-1900 (2005).

239. Id. at 1905-06 (administrative costs and overpayments); id. at 1915 (participation rates).

240. Graetz, supra note 185, at 290. 
Medicare) payroll tax. Although in some cases this would merely reduce or eliminate workers' payroll-tax obligations, Graetz contemplates that in many cases (primarily involving workers with dependent children) the new wage subsidies would substantially exceed the amounts of workers' payroll-tax obligations. In those situations, "employers [would] adjust their employees' paychecks to provide 'negative withholding' or additional take-home pay." ${ }^{241}$ An employer would be compensated for its wage subsidy payments by a corresponding dollar-for-dollar reduction in its required payroll-tax deposits (or by a credit on the employer's income-tax return, in the unlikely event that reducing an employer's required payroll-tax deposits to zero did not fully compensate the employer) ${ }^{242}$ As with the EITC, the benefit amounts under the new wage subsidy would be sensitive to the number of a worker's dependent children. ${ }^{243}$

Graetz suggests that workers with annual earnings of $\$ 20,000$ or less should be entitled to the maximum subsidy amount (as adjusted for family size), and that subsidy amounts should be gradually phased out for workers with annual earnings between $\$ 20,000$ and $\$ 50,000 .{ }^{244}$ Basing subsidy amounts on annual incomes would seem to require the filing of income-tax returns by subsidy recipients, which would defeat the purpose of Graetz's overall proposal. To avoid this problem, Graetz proposes basing subsidy amounts on hourly wage rates (and the number of eligible children). ${ }^{245}$ Graetz acknowledges that determining subsidy amounts without regard to annual income can produce only "rough justice" and "might allow offsets [that is, subsidies] to some who do not deserve them," but he concludes that the gain in simplification outweighs the loss of precision. ${ }^{246}$

Beyond the roughness of the justice of the proposed subsidy, there is another significant problem. As Graetz explains, "[E]mployers would have to report employees' hourly wage rates to the IRS." ${ }^{247}$ This would impose a new administrative burden on employers and on the IRS, but that is not the main concern. The larger issue is the potential for a new kind of cheating. An employer would be able to increase an employee's wage subsidy, at no cost to itself, by correctly reporting to the IRS the employee's pretax earnings for a pay period but falsely claiming the earnings resulted from a lower-than-actual wage rate and a higher-than-actual number of hours worked.

My interest here is not in evaluating the ultimate merits of the proposed EITC replacement, but in considering whether something along the lines of the proposed replacement would have emerged at some point during the postwar

241. Id. at 291.

242. Id. at 292 n.145.

243. Id. at 291 n.141.

244. Id. at 291.

245. Id. at 292 n.144.

246. $I d$.

247. Id. at 292 n.145. 
era if the income tax had not been a mass tax-that is, if the United States had emerged from World War II with a mass sales tax and an income tax imposed only on the affluent. Graetz has shown that something roughly resembling the EITC-in terms of both subsidy amounts and non-welfare-based administration-is technically possible without a mass income tax, but it does not necessarily follow that Congress would have enacted such a program in the absence of a mass income tax.

Objections to the EITC substitute are relevant to the extent they would have weakened the political viability of the EITC substitute in the alternate postwar universe in which low-income workers were not within the income-tax system. In pondering that counterfactual, bear in mind that the posited circumstances are very different from those that would exist today if Congress decided to scrap the mass income tax in favor of Graetz's overall proposal. Given that the EITC now exists, it seems likely that moving to Graetz's VATplus-income-tax system would require the adoption of an EITC replacement along the lines he describes. It is a very different question, however, whether something like Graetz's EITC replacement would have been enacted if there had never been a mass income tax, and thus no EITC in need of replacement.

Considering whether something like the EITC replacement would have appeared in the absence of mass income taxation requires a review of the adoption and growth of the actual EITC. The EITC was first introduced (as a temporary measure) in 1975, largely due to the efforts of Senator Russell Long. ${ }^{248}$ As originally enacted, the credit equaled $10 \%$ of the first $\$ 4000$ of earned income, reduced by $10 \%$ of the amount by which income exceeded $\$ 4000$. Only workers with dependent children were eligible for the credit. The credit was technically refundable, in that a credit claimant would receive a check from the Treasury for the amount by which the credit exceeded the claimant's pre-credit income-tax liability. From a broader perspective, however, Congress understood the credit as payroll-tax relief, rather than as a true transfer payment. In the words of the Senate Finance Committee, "The credit is set at ten percent in order to correspond roughly to the added burdens placed on workers by both employee and employer social security contributions. ${ }^{249}$

248. Tax Reduction Act of 1975, Pub. L. No. 94-12, § 204, 89 Stat. 26, 30. The credit was made a permanent part of the Internal Revenue Code in 1978. Revenue Act of 1978, Pub. L. No. 95-600, $\S$ 103-104, 92 Stat. 2761, 2770-71. For an excellent political history of development of the EITC, see Dennis J. Ventry, Jr., The Collision of Tax and Welfare Politics: The Political History of the Earned Income Tax Credit, 1969-99, 53 NAT’L TAX J. 983 (2000).

249. S. REP. NO. 94-36, at 11 (1975), reprinted in 1975 U.S.C.C.A.N. 54, 63-64. The 10\% rate of credit was nearly identical to the $9.9 \%$ rate of the combined employer and employee Social Security payroll taxes (consisting of an employee tax at $4.95 \%$ and an employer tax at the same rate), and less than the $11.7 \%$ rate produced by the combination of the Social Security taxes and the taxes relating to Medicare (HI) benefits (a $0.9 \%$ employee tax and an equal-rate employer tax). Tax Policy Center Historical Payroll Tax Rates http://www.taxpolicycenter.org/taxfacts/Content/PDF/ssrate_historical.pdf (last visited Oct. 25, 2009). 
The 1975 EITC grew out of Milton Friedman's 1962 proposal for a negative income tax (NIT) ${ }^{250}$ Under Friedman's proposal, a person would have negative income equal to the excess of the sum of his standard deduction and personal exemptions over his gross income, and would receive a transfer payment from the government equal to $50 \%$ of his negative income. The EITC borrowed from the NIT the idea of using the income-tax system as the vehicle for an antipoverty transfer program. But the NIT penalized work (by reducing the amount of the negative tax as earnings rose above zero), while the EITC rewarded work (by increasing the amount of the credit as earnings rose above zero). It is tempting to cite the close connection between the NIT and the EITC as powerful evidence that the EITC was a creature of mass income taxation from its inception. The NIT emerged in the context of mass income taxation and made sense only in that context, and the NIT eventually gave rise to the EITC, which was also premised on the existence of mass income taxation. Without mass income taxation, then, it seems there would have been no NIT proposal, and no EITC enactment.

That conclusion, however, would be too hasty. As for the NIT itself, it does not do justice to Milton Friedman's creative capacity to suppose that he could not have conceived of the NIT if the income tax had not been a mass tax in 1962. Nor is it true that any legislation inspired by the NIT would have necessarily relied on the income-tax system for its implementation. In fact, President Nixon's Family Assistance Plan (FAP) - which passed the House in 1969, and which was in substance a negative income tax of sorts-did not rely on tax-based administration (either income tax or payroll tax). ${ }^{251}$

But in the end the EITC became law and the FAP did not, and the explanation for those different outcomes involves the tax-based nature of the EITC. The EITC succeeded where the FAP had failed because it targeted its benefits towards the working poor-the "deserving" poor in the view of Senator Long and many other members of Congress. ${ }^{252}$ Although it is barely possible to imagine a wage subsidy administered by a welfare bureaucracy, under which the amount of benefits is positively associated with the amount of the recipient's earnings, such a system would involve horrendous administrative difficulties. By contrast, a mass income tax-with the mechanisms for measuring and reporting earned income already in place-can be readily adapted for use as a vehicle for delivering the desired sort of wage subsidy. The only politically feasible substantive design for a subsidy—a subsidy that would "make work

250. Milton Friedman, CAPitAlism And Freedom 191-92 (2d prtg. 1982). For the intellectual and political connections between Friedman's proposal and the EITC, see Ventry, supra note 248, at 985-96, and Lawrence Zelenak, Redesigning the Earned Income Tax Credit as a Family-Size Adjustment to the Minimum Wage, 57 TAX L. REV. 301, 302-04 (2004).

251. On the Family Assistance Plan, see Ventry, supra note 248, at 988-92. For the approval of the Family Assistance Plan by the House, see Warren Weaver Jr., President's Welfare Plan Passes House, 243 to 155, NEW YORK Times, Apr. 17, 1970, at 1.

252. Ventry, supra note 248 , at 992. 
pay"-virtually mandated tax-based administration rather than welfare-based administration.

This is not enough, however, to establish that no program similar to the EITC would have been enacted in the 1970s, but for the income tax. Although tax-based administration appears to have been a necessity for a politically viable program, in the absence of a mass income tax a program administered through the payroll-tax system-that is, a program similar to that proposed by Graetz-might have been enacted. In lieu of the EITC, Congress might have enacted a payroll-tax-based system, under which (1) a qualified worker with an hourly wage rate associated with annual wages of $\$ 4000$ or less would not be subject to the employee's payroll tax, and (2) the employer's payroll tax on those same wages would be forgiven on the condition that the employer increased the employee's take-home pay by the amount of the forgiven tax. In the absence of a mass income tax, it is possible that such a program could have been enacted in the mid-1970s. It is also possible, however, that such a program would not have been enacted. Recall the objections noted above to Graetz's proposal, relating to the roughness of the justice it would produce in some cases and to the administrative burdens and the potential for cheating inherent in a transfer program keyed to hourly wage rates. These objections-which did not apply to the EITC but which would have applied to the payroll-tax-based program-might have been enough to have doomed the program. This counterfactual question is too close to call. All that can be said is that the enactment of a payroll-tax-based program in the absence of a mass income tax would not have been unimaginable, but that it would have been far from a sure thing.

What is almost a sure thing, however, is that a payroll-tax-based systemhad it been enacted in 1975-would not have evolved in a way similar to the evolution of the EITC. The actual EITC has hugely outgrown its origins as a de facto nonrefundable credit (that is, as an offset for a portion of payroll taxes, rather than as a true transfer program). Legislation enacted in 1990 made it possible, for the first time, for the EITC to function as a true transfer program-albeit to a very limited extent. ${ }^{253}$ Under the 1990 legislation, it was possible for a recipient's EITC amount to exceed her total payroll-tax burden, but by a maximum of only $\$ 115 .^{254}$ The dam broke three years later, when legislation raised the credit to $34 \%$ for a worker with one qualifying child and to $40 \%$ for a worker with two or more qualifying children. ${ }^{255}$ Both percentages

253. Omnibus Budget Reconciliation Act of 1990, Pub. L. No. 101-508, § 11111, 104 Stat. 1388, $1388-408$.

254. Zelenak, supra note 238 , at 1909-10.

255. Omnibus Budget Reconciliation Act of 1993, Pub. L. No. 103-66, § 13131, 107 Stat. 312, 433. 
more than doubled the $15.3 \%$ rate of the total payroll-tax burden, ${ }^{256}$ resulting in genuine transfer payments under the EITC on a large scale.

The key question for the alternate postwar tax history is whether something resembling this development-that is, a large-scale, genuine transfer (rather than tax-relief) program, with tax-based rather than welfare-based administration-could have occurred if the program enacted in 1975 had been payroll-tax-based rather than income-tax-based. There is a strong argument that the post-1975 development of the EITC into a massive genuine transfer program without welfare-based administration was something of a historical accident. ${ }^{257}$ The basic steps of the argument are: (1) Congress is not ordinarily willing to tolerate the high overpayment rates associated with tax-based administration of antipoverty transfer programs; (2) Congress was willing to accept tax-based administration of the EITC in 1975 only because it understood the EITC as de facto payroll-tax relief rather than as a genuine transfer program; and (3) by the time Congress greatly expanded the EITC in 1993, transforming it into a genuine transfer program, the members had largely forgotten the original rationale for permitting tax-based administration of the credit, and did not realize that the original rationale would not support taxbased administration of an EITC transformed into a true transfer program.

Congress could forget the original understanding of the relationship between the credit and the payroll tax because the relationship was always merely notional rather than formal. Although the 1975 Congress understood the EITC as a payroll-tax offset, nothing in the statutory EITC rules officially designated the credit as a payroll-tax offset or created any functional connection between the EITC and payroll taxes. The situation would have been very different if, in the absence of a mass income tax in 1975, Congress had enacted a payroll-tax-based program in lieu of an EITC. In that case, the nature of the program as payroll-tax relief would have been formal rather than merely notional and could scarcely have been forgotten by Congress over time. If someone had then proposed, in or around 1993, turning that program of mere tax relief into a massive program of transfer payments, it seems likely that Congress would have balked. It would have viewed the proposal as one for an utter transformation of the program, rather than as a mere expansion. Congress would have been unwilling to approve billions of dollars of antipoverty transfer payments without the safeguards against overpayments provided by welfarebased administration. Nor is it at all likely that Congress would have enacted a welfare-based transfer program similar in substance to the 1993 expansion of

256. The total payroll-tax burden-consisting of the employee's OASDI and HI taxes, and the employer's OASDI and HI taxes-has held steady at $15.3 \%$ since 1990 . Tax Policy Center, supra note 249.

257. Zelenak, supra note 238, at 1906-11. 
the EITC, because of the great difficulty of administering a wage subsidy through a welfare bureaucracy. ${ }^{258}$

To sum up: payroll-tax relief similar in substance to the 1975 version of the EITC would have been conceivable in the absence of a mass income tax, but it is highly unlikely that any program substantively similar to the 1993 transformation of the EITC into a genuine transfer program could have occurred without mass income taxation. The difference between the actual history and the alternate history is that the structure of the EITC obscured the extent to which the 1993 legislation broke new ground, whereas under the alternate history the lack of precedent for a 1993-type expansion would have been obvious.

\section{E. Employer-Provided Health Insurance and National Health Insurance}

Compared with other affluent nations, the United States is exceptional for its lack of universal health-insurance coverage and for the dominance of employer-provided health insurance. Employment-based health insurance is encouraged by the federal income tax, which excludes from an employee's income the value of employer-provided coverage ${ }^{259}$ but which does not generally allow a corresponding deduction for the cost of individually purchased health insurance. ${ }^{260}$ Of course, the income-tax treatment of health insurance would have been much less significant if the United States had emerged from World War II with the income tax as a class tax and a retail sales tax as the federal mass tax and if the income tax had remained a class tax in later decades. This raises the question whether postwar health-insurance developments would have been significantly different in the absence of a mass income tax. In particular, is it possible that the United States would have some form of universal health insurance today if the postwar mass tax had been a retail sales tax (or VAT) rather than the income tax? At first glance, this seems plausible. The argument would be (1) that the income-tax favoritism for employer-provided health insurance encouraged the spread of employment-based coverage, (2) that the tax-subsidized growth in coverage made employment-based coverage a politically viable alternative to national health insurance, and (3) that results would have been different under a retail sales tax because the sales tax would not have had the same favoritism for employer-provided insurance. Upon closer examination, however, it seems unlikely that a retail sales tax would have made

258. In addition, Congress would have had to either (1) accept the complexities and expense involved in creating a new federal welfare bureaucracy to administer the new transfer program, or (2) entrust state welfare bureaucracies of varying trustworthiness with the task of accurately distributing billions of federal dollars.

259. I.R.C. $\S 106$ (2002).

260. Health-insurance premiums qualify as medical expenses under I.R.C. $\S 213$, but like all other medical expenses they are deductible only to the extent total expenses exceed $7.5 \%$ of adjusted gross income and only if the taxpayer itemizes deductions rather than claims the standard deduction. Healthinsurance premiums of self-employed individuals are fully deductible. IRC §162(i) (2008). 
a major difference in postwar health-insurance developments. The reasons for that conclusion are explored below.

In his successful 1948 campaign, President Truman ran on a platform featuring national health insurance as one of its major planks. ${ }^{261}$ Following the election, however, Truman never came close to persuading Congress to follow his lead. ${ }^{262}$ Opponents of national health insurance-the American Medical Association (AMA) most prominently, but also hospitals, insurance companies, and many employers - argued that national health insurance was unneeded in light of the growth of employment-based coverage. A prominent AMA advertisement featured a well-known nineteenth-century painting of a physician ministering to a sick girl (The Doctor, by Sir Samuel Luke Fildes), along with the AMA's message: "Voluntary Health Insurance-The American Way Will KEEP POLITICS OUT OF THIS PICTURE."263 As the creators of that advertisement observed, opponents of national health insurance could not expect to "beat something with nothing," and private health insurance (overwhelmingly employer-provided) was the something with which to defeat national health insurance. ${ }^{264}$

Employment-based coverage was spreading rapidly at the time. Although only two- to three-million workers and dependents had had health insurance coverage (employment-based, in the vast majority of cases) in the early $1930 \mathrm{~s},{ }^{265}$ the number had grown to 12.3 million ( $9 \%$ of the population) by 1940 , and to 32 million by $1945 .^{266}$ The impressive growth continued after the end of the war; by 1950, 76.6 million Americans - for the first time, a majority of the populationhad private health-insurance coverage. ${ }^{267}$

To what extent was this growth attributable to the favorable income-tax rules governing employment-based insurance? The more-than-four-fold increase from the early 1930s to 1940 presumably owed little to the income tax, since the income tax was not a mass tax during that period. It is more plausible that the post-1940 growth owed something to the income tax. It is worth noting, however, that the income-tax exclusion for employer-provided coverage was vague and uncertain until 1954. Before 1954, the Internal Revenue Code was silent on the income-tax status of employer-provided health insurance. A 1920 administrative ruling had concluded that employees were not taxable on employer-paid premiums on group policies, ${ }^{268}$ and another ruling to similar

261. HACKER, supra note 186, at 223.

262. Id. at 224 .

263. Id. at 227.

264. Frank D. CAMpion, The AMA AND U.S. HeAlth Policy SinCE 1940, at 162 (1984).

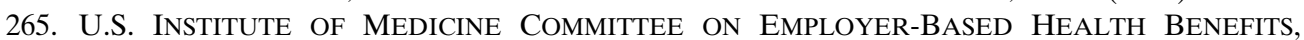
EMPLOYMENT AND HEALTH BENEFITS: A CONNECTION AT RISK 66 (1993), cited in HACKER, supra note 186 , at 209.

266. HeAlth Insurance Association of AmericA, Source BoOK of HeAlth Insurance

DATA 41 (1996), cited in HACKER, supra note 186, at 214.

267. Id.

268. 10 L.O. 1014, 2 C.B. 88, 89-90 (1920), obsoleted by Rev. Rul. 69-31, 1969-1 C.B. 307, 308. 
effect was issued in $1943 .{ }^{269}$ Although the Internal Revenue Service consistently took this position with respect to employer-provided group insurance, it looked less kindly upon employer-provided individual insurance. A 1953 ruling that employer-paid premiums on individual insurance were includable in the employee's income ${ }^{270}$ appears to have furnished part of the impetus for the codification of the exclusion in 1954. President Eisenhower asked Congress to codify the exclusion in order to encourage "insurance and other plans adopted by employers to protect their employees against the risks of sickness ... by removing the present uncertainties in the tax law." ${ }^{271}$ Congress responded by enacting Internal Revenue Code $\S 106$ as part of the Revenue Act of $1954 .^{272}$ The vagueness and informal status of the exclusion before 1954 may have encouraged employment-based coverage less than a clear statutory exclusion would have done. ${ }^{273}$ By the time the 1954 legislation cured the problems of vagueness and informality, the victory over Truman's national health insurance proposal had already been won.

Despite the caveats noted above, it is reasonable to conclude that the pre1954 de facto favorable tax treatment of employer-provided insurance played a role in the growth of employment-based coverage, which in turn played a role in the defeat of Truman's proposal. Whether the favorable tax treatment was outcome-determinative in the defeat of national health insurance is impossible to say. Given the considerable prewar growth in employment-based coverage (that owed little to the income-tax rules, in the absence of a mass income tax), and the wartime encouragement of employment-based coverage by the exemption of fringe benefits from wage and price controls, ${ }^{274}$ it is conceivable that employment-based coverage would have been sufficient by the late 1940s to prevent the enactment of national health insurance, even in the absence of a tax advantage.

For present purposes, however, the crucial question is not whether the favorable income-tax treatment was outcome-determinative, but whether the national health-insurance outcome would have been any different under a

269. Special Ruling, 3 CCH 1943 FED. TAX REP. II 6587 (1943).

270. Rev. Rul. 210, 1953-1 C.B. 114.

271. President's Budget Message, 100 CONG. REC. 570 (1954), quoted in Jay A. Soled, Taxation of Employer-Provided Health Coverage: Inclusion, Timing, and Policy Issues, 15 VA. TAX REV. 447, 451 n.19 (1996).

272. Revenue Act of 1954, Pub. L. No. 83-591, § 106, 68A Stat. 3, 32. The new exclusion applied to "contributions by the employer to accident or health plans for compensation (through insurance or otherwise) to his employees for personal injuries or sickness." I.R.C. § 106 (1954). Despite President Eisenhower's plea for certainty, this language had uncertainties of its own. It was unclear, for example, whether employer-paid premiums on nongroup insurance would satisfy the "plan" requirement of the new provision. See Note, Taxation of Employee Accident and Health Plans Before and Under the 1954 Code, 64 YALE L.J. 222, 242-43 (1954).

273. See Melissa A. Thomasson, The Importance of Group Coverage: How Tax Policy Shaped U.S. Health Insurance, 93 AM. ECON. REV. 1373 (2003) (concluding that the 1954 codification of the exclusion increased the amount of health insurance coverage purchased by $9.5 \%$ ).

274. HACKER, supra note 186, at 218. 
federal retail sales tax. Those who advocated a retail sales tax during World War II consistently assumed the tax would not apply to medical services. ${ }^{275}$ Almost certainly, then, employer-provided health insurance would have been just as free of tax under a postwar retail sales tax as it was under the postwar income tax. It is true that a retail sales tax would not have favored employerprovided health insurance over individual coverage, as did the actual income tax ${ }^{276}$ but that difference would not have been important in the battle over national health insurance.

Employment-based group insurance had three immense advantages over individual insurance, such that it would have dominated even with a level playing field with respect to taxes. Employment-based insurance solved the problem of adverse selection and could be administered much more cheaply than individual coverage. ${ }^{277}$ In addition, during World War II, employmentbased coverage was encouraged over individual coverage (purchased by individuals with their cash wages) because fringe benefits were excluded from wage and price controls. ${ }^{278}$ By the late 1940s, then, the dominance of employment-based coverage under a retail sales tax (exempting both employment-based coverage and individual coverage) would not have differed greatly from the dominance of employment-based coverage under the actual mass income tax.

In any event, what opponents of national health insurance needed was a vibrant and growing private-health-insurance industry; for purposes of defeating national health insurance, the relative popularities of employmentbased and individual coverage were immaterial, as long as the public was satisfied with the overall private-insurance situation. Although the main thing opponents of national health insurance wanted from the tax system was favorable treatment for employment-based coverage (because of the tremendous nontax advantages of employer-group coverage over individual insurance), they also had every reason to welcome favorable tax treatment for individual coverage. ${ }^{279}$ Since a postwar retail sales tax would have been just as

275. See, e.g., HARDY, supra note 104, at 23 n.1 ("The exemption of medical care . . is based partly on the desirability of encouraging such expenditures and partly on the unusual difficulties involved in applying the tax to them.").

276. Health-insurance premiums paid by individuals on non-employment-based coverage were not deductible at all until the introduction of the medical-expense deduction in 1942 . Such premiums did qualify as medical expenses under the 1942 legislation, but an individual could deduct her medical expenses only to the extent her total medical expenses exceeded $5 \%$ of her income. Revenue Act of 1942, Pub. L. No. 77-753, § 127(a), 56 Stat. 798, 825.

277. HACKER, supra note 186, at 199-200.

278. Id. at 218 .

279. This is demonstrated by the health-insurance-related provisions of the Revenue Act of 1954 . One of the goals of proponents of the Act was to strengthen private health insurance, thus forestalling any future resurgence of interest in national health insurance. HACKER, supra note 186, at 239-40. In addition to encouraging employment-based coverage by codifying the exclusion, the Act also encouraged individual health insurance by lowering the percentage-of-income floor on the deductibility of medical expenses (including individual insurance premiums) from 5\% to 3\%. Revenue Act of 1954, Pub. L. No. 83-591, §213, 68A Stat. 3, 69 (1954). 
favorable to employment-based insurance as the actual mass income tax and would have been even more favorable than the income tax to individual insurance, it would have been at least as effective as the income tax in thwarting the advocates of national health insurance.

\section{F. The Home-Mortgage-Interest Deduction}

The home-mortgage-interest deduction is as old as the modern income tax. ${ }^{280}$ Although the Revenue Act of 1913 made no specific mention of homemortgage interest, the Act provided a deduction for all interest expense. ${ }^{281}$ As Christopher Howard has noted, there is "no evidence that this deduction [that is, the home-mortgage-interest deduction as part of the general interest deduction] was deliberately created to promote homeownership." ${ }^{282}$ Howard plausibly suggests that the deduction for home-mortgage interest-and for consumption-related interest more generally-may have been a legislative response to the difficulty of untangling business interest expense (properly deductible under income tax theory) from consumption-related interest expense. ${ }^{283}$

As long as the income tax remained an elite tax rather than a mass tax, the home-mortgage-interest deduction was of direct interest to only a small percentage of the population. As Howard remarks, "The transformation of the individual income tax from an elite tax to a mass tax around World War II had a profound impact on the home-mortgage-interest deduction, for it meant that many more home owners were paying income taxes and therefore potentially eligible to take the deduction." 284 The "potentially" qualification is important; the deduction was available only to taxpayers not claiming the standard deduction, and in 1944 (for example) over $80 \%$ of all taxpayers claimed the standard deduction. ${ }^{285}$

The percentage of taxpayers claiming the standard deduction has varied considerably during the postwar era, largely in response to inflation and to occasional changes in the nominal amount of the standard deduction. Between 1950 and 1963, for example, the trend was decidedly downward; the percentage fell from $80.4 \%$ to $55.4 \%,{ }^{286}$ with the result that the mortgage-interest deduction became meaningful to many more homeowners. Throughout the postwar

280. The historical background on the home-mortgage-interest deduction offered here is limited to the history needed to evaluate whether the deduction would have survived the postwar era if the income tax had remained a class tax. For what will surely be acknowledged as the definitive history of the deduction, see Dennis J. Ventry, Jr., The Accidental Deduction: A History and Critique of the Tax Subsidy for Mortgage Interest, 73 LAW \& CONTEMP. PROBS. 235 (2010).

281. Revenue Act of 1913, Pub. L. No. 16, § II(B), 38 Stat. 114, 168.

282. Christopher Howard, THe Hidden Welfare State 49 (1997).

283. Id. at $53-54$.

284. Id. at 94.

285. C. HARry Kahn, Personal Deductions in the Federal InCOME TAX 163 tbl.57 (1960).

286. Tax Policy Center Standard, Itemized, and Total Deductions Reported on Individual Income Tax Returns, Tax Years 1950-2005 (2007), available at www.taxpolicycenter.org. 
period, however, most taxpayers have always claimed the standard deductionover $60 \%$ in recent years. ${ }^{287}$ Although one might reasonably think of the homemortgage-interest deduction (and the other itemized deductions) as situated in a semi-elite tax within the mass income tax, it does not appear that this way of thinking has been common. The deduction has remained extremely popular with both Congress and the general public, despite being available only to taxpayers not claiming the standard deduction. ${ }^{288}$

The deduction was so politically secure for many years that homebuilders and real-estate brokers found no need to lobby to protect it until 1963. Even then, their efforts were directed not against a proposal singling out the mortgage-interest deduction for reform but rather against a Kennedy Administration proposal (which was ultimately defeated) to subject all itemized deductions to a $5 \%$-of-income floor. ${ }^{289}$ The first significant threats focused specifically on the mortgage-interest deduction did not appear until the fundamental tax-reform proposals of the early 1980s. The Fair Tax Act proposed by Senator Bill Bradley and Representative Richard Gephardt would have effectively converted the deduction to a $14 \%$ credit, and the Treasury Department's 1984 reform proposal would have limited the deduction to interest on mortgages on primary residences. ${ }^{290}$ Even then, however, the deduction survived the Tax Reform Act of 1986 formally unscathed, except for the restriction of the deduction to interest on a principal residence and one other home. ${ }^{291}$ The deduction suffered another minor blow the next year, when legislation limited the deduction to the interest on $\$ 1$ million of acquisition indebtedness and $\$ 100,000$ of other debt secured by a qualified residence. ${ }^{292}$

Despite the modest limitations imposed on the deduction in the 1980s, it remains a very healthy tax expenditure, estimated by the Staff of the Joint Committee on Taxation at $\$ 80.1$ billion for 2009 , ${ }^{293}$ and it is apparently in no political danger. The question here is whether the deduction would have fared less well if the postwar federal tax structure had consisted of a retail sales tax (or a VAT) and an elite income tax, rather than a mass income tax. In

287. Id. The postwar low was $51.7 \%$ in 1970.

288. See, e.g., Sandra Fleishman, Tax Proposal May Not Float, but It Sure Is Making Waves, WASH. Post, Nov. 12, 2005, at F1 (reporting the results of a survey commissioned by the National Association of Home Builders - that $75 \%$ of likely voters opposed the proposal of the President's Advisory Panel on Federal Tax Reform to greatly reduce the scope of the home-mortgage-interest deduction).

289. HOWARD, supra note 282, at 103-04.

290. Id. at 107-08; U.S. DEP'T OF THE TREASURY, TAX REFORM FOR FAIRNESS, SIMPLICITY AND ECONOMIC GROWTH 83 (1984).

291. Tax Reform Act of 1986, Pub. L. No. 94-514, § 511, 100 Stat. 2085, 2246 (1986). The qualification in the text, "formally unscathed," is necessary because the value of the deduction was reduced by the Act's increase in the standard deduction and decrease in marginal tax rates.

292. Omnibus Budget Reconciliation Act of 1987, Pub. L. No. 100-203, §10102, 101 Stat. 1330, 133084 (1987). Because they were not indexed for inflation, these dollar limits have become somewhat more significant in the years since their enactment.

293. StAFF OF THE J. COMM. ON TAXATION, Estimates OF FEDERAL TAX EXPENDITURES FOR FISCAL YEARS 2008-2012, at 51 tbl.2 (2008). 
attempting to answer that question, it is important to note that the distribution of tax benefits from the deduction under the actual mass income tax is not hugely different from how the tax benefits of the deduction would have been distributed under a class income tax. In 2007 (the most recent year for which data are available), $73.0 \%$ of the benefit of the home-mortgage-interest deduction (in terms of dollars of tax reduction) accrued to taxpayers with incomes above $\$ 100,000$, and $85.3 \%$ to taxpayers with incomes above $\$ 75,000 .^{294}$ One can only speculate as to the exemption level of a class income tax partnered with a retail sales tax, but something in the range of $\$ 75,000$ to $\$ 100,000$ is plausible. Assuming a $\$ 100,000$ exemption, nearly three-quarters of the dollar amount of the tax expenditure would remain under the class income tax. The dollars of tax benefit lost by homeowners with incomes below $\$ 100,000$ (and thus not subject to the income tax) would not be tremendously significant from an economic perspective.

Those lost dollars might, however, be very significant in terms of the public perception of the deduction, and thus in terms of the deduction's political fate. If the income tax applied only to those in, say, the top $20 \%$ of the income distribution, it would be glaringly obvious to all that $100 \%$ percent of the benefits of the mortgage-interest deduction were enjoyed by the top $20 \%$ of the income distribution. In fact, the benefits would be only modestly more skewed in favor of the affluent than under current law, but, in contrast with the current situation, the skewing would be impossible to miss. Under the mass income tax, one suspects the dominant attitude toward the deduction among the general public is along the following lines: (1) most people own their homes, (2) most homeowners have mortgages, ${ }^{295}$ and (3) most people pay federal income tax; therefore, (4) the benefits of the home-mortgage-interest deduction are widely distributed among the population, and (5) the deduction deserves to be retained. Under the alternate tax system, by contrast, the dominant thinking might be (1) most people don't pay income tax; therefore, (2) most people get no benefit from the mortgage-interest deduction, and (3) the deduction is an unwarranted subsidy for the affluent and should be repealed. This attitude might be especially common if housing were exempt from the retail sales tax (or VAT). In that case, the public (and Congress) might reason that the exemption of housing from the retail sales tax is far more attractive than the mortgageinterest deduction in its distributional effects and that the exemption is a sufficient tax subsidy for housing. The obvious conclusion of that line of reasoning would be the repeal of the deduction. Would the retail sales tax (or VAT) have exempted housing? Although various approaches to housing are

294. Author's calculations, based on id. at 76 tbl.6.

295. In 2007, 68.3\% of all occupied dwelling units in the United States were owner-occupied and $67.1 \%$ of all owner-occupied dwelling units were subject to mortgages. U.S. CENSUS BUREAU, AMERICAN HOUSING SURVEY FOR THE UNITED STATES: 2007, at 46 tbl.2-1. 162 tbl.3-15 (2008). Thus, the first two assumptions are correct. It does not follow that most dwelling units are owner-occupied and mortgaged, but almost half are $(45.8 \%)$. 
possible under a retail sales tax (or VAT) — complete exemption, taxation of sales of new homes but not of sales of existing homes, or taxation of sales of both new and existing homes ${ }^{296}$ - sales-tax proposals during World War II generally assumed housing would be completely exempt. ${ }^{297}$ It is likely, then, that the postwar sales tax (or VAT) would also have exempted housing, resulting in increased political vulnerability of the mortgage-interest deduction under the class income tax.

None of this proves, of course, that the home-mortgage-interest deduction would have been repealed or sharply restricted if the income tax had been a class tax in postwar America. After all, the deduction was never challenged during almost three decades of the income tax as a class tax before World War II. It does seem fair to conclude, however, that the deduction would have been considerably more threatened under a two-tax system than it has been under the actual mass income tax. ${ }^{298}$

\section{G. Employer-Provided Pensions}

The three cornerstones of the favorable income-tax treatment of employerprovided pensions-immediate deductibility of pension contributions by employers, deferral of employees' tax on employers' contributions until receipt by employees of cash distributions, and similar deferral of employees' tax on the investment return on employers' contributions-have been in place since the Revenue Act of $1926 .^{299}$ Only about $7 \%$ of the private civilian labor force was covered by private pensions in 1926, and that percentage actually declined

296. The VAT proposed by Michael Graetz would be imposed on new residential construction, but not on resales of existing homes. Graetz, supra note 185, at 288.

297. See, e.g., HARDY, supra note 104, at 23 n.1 ("Exemption of housing expenditure is necessary to avoid gross discrimination as between those who pay rent and those who own their own homes.").

298. The distribution of the benefits of the charitable-contribution deduction is even more skewed in favor of affluent taxpayers than the distribution of the benefits of the mortgage-interest deduction. In $2007,82.7 \%$ of the benefit of the charitable-contribution deduction (in terms of dollars of tax reduction) was enjoyed by taxpayers with incomes above $\$ 100,000$, and $90.6 \%$ by taxpayers with incomes above $\$ 75,000$. See STAFF OF THE J. COMM. ON TAXATION, supra note 293, at 72 tbl.6. At first glance, then, it might seem that the charitable-contribution deduction would also have been politically vulnerable under a postwar class income tax, for essentially the same reasons developed in the text with respect to the mortgage-interest deduction. But suppose-as seems likely-the public views homeowners claiming the mortgage-interest deduction as the ultimate beneficiaries of that deduction, but views charities as the ultimate beneficiaries of the charitable-contribution deduction (with the taxpayers claiming the deduction as mere conduits for the subsidy from the government to the charities). In that case, the political threat to the charitable-contribution deduction would be much less than the threat to the mortgage-interest deduction.

299. Revenue Act of 1926, Pub. L. No. 69-20, § 219(f), 44 Stat. 9, 33. The 1926 Act extended to all employer-provided pensions the favorable tax treatment that the Revenue Act of 1921 had provided for stock bonus and profit-sharing plans. Revenue Act of 1921, Pub. L. No. 67-98, § 219(f), 42 Stat. 227 , 247. For an excellent summary of the early legislative history of the tax treatment of employer-provided pensions, see Patricia E. Dilley, The Evolution of Entitlement: Retirement Income and the Problem of Integrating Private Pensions and Social Security, 30 LOY. L.A. L. REV. 1063, 1142-58 (1997). For the current income tax provisions governing employer-provided pensions, see I.R.C. $\S \S 72$, 401-423 (2008). 
slightly during the first decade of favorable income-tax treatment. ${ }^{300}$ In the mid1930s, however, there began a forty-year period of impressive growth in private pension coverage, with coverage reaching approximately $40 \%$ by the mid1970s. ${ }^{301}$ Coverage growth since the mid-1970s has been much more modest: $51 \%$ of the private labor force participated in employment-related retirement plans (defined contribution, defined benefit, or both) in 2007..$^{302}$

Imagining the postwar development of employer pensions under a retail sales tax and a class income tax provokes two major questions. First, would the income tax rules governing employer pensions be about the same today under a class income tax as they are under the actual mass income tax? Second, and more important, would the extent and distribution of employer pension coverage be about the same today under the alternate tax structure as under the actual mass income tax?

Both questions are most plausibly answered in the affirmative. This is an area in which the choice of a mass income tax over a retail sales tax has probably made little difference. A chart of the share of the private civilian labor force covered by private pensions over time shows growth at a nearly constant rate from about 1935 to about $1975 .^{303}$ Although the decades of growth include the war years in which the federal income tax became a mass tax, nothing in the chart suggests special significance for the war years; the nearly constant growth rate began about seven years before the income tax became a mass tax and continued for three decades after the war's end. In his study of the growth of private pensions, Jacob S. Hacker identifies three primary reasons for the growth from the mid-1930s to the mid-1940s: (1) the introduction of Social Security in the mid-1930s encouraged employer pensions "both because it lowered the amount that employers had to spend to provide adequate retirement income and because, ironically, it allowed employers to target pension benefits more effectively to better-paid employees"; (2) the favorable income tax treatment introduced in 1926 became more significant as marginal tax rates on employers and highly compensated employees rose during the New Deal and World War II; and (3) the exemption of pensions (along with other fringe benefits) from wartime wage and price controls encouraged employers to provide pensions in lieu of cash raises. ${ }^{304}$ Although the second of these three reasons is an income tax reason, it has nothing to do with the conversion of the income tax from a class tax to a mass tax; the wartime income tax would have featured high marginal rates on corporations and high-income individuals even if it had remained an elite tax.

300. HACKER, supra note 186, at 89 fig.2.1.

301. Id.

302. U.S. Census Bureau, Statistical AbSTRACT OF THE United STATES: 2009, at 350 tbl.532 (2009).

303. HACKER, supra note 186, at 89 fig.2.1.

304. Id. at 113. On the significance of the exemption from wage and price controls, see also HOWARD, supra note 282, at 121. 
Hacker explains the continued growth in pension coverage after the end of the war without reference to the new mass income tax. Rather, he points to the failure of Congress to respond to organized labor's calls for Social Security expansion, which resulted in labor successfully seeking increased retirement security through collective bargaining instead. ${ }^{305}$ This turn to pensions as a subject of collective bargaining was encouraged by the National Labor Relations Board, which ruled that federal law required the inclusion of fringe benefits among the subjects of collective bargaining. ${ }^{306}$

Hacker discusses one other way in which the income tax rules may have contributed to the growth of private pensions, although he views it as of little significance. The Revenue Act of 1942 introduced pension-nondiscrimination rules, under which favorable tax treatment for employer pensions was available only if an employer offered pensions to at least $70 \%$ of those full-time workers employed for five or more years ${ }^{307}$ It is obvious how a nondiscrimination rule could lead to increased pension coverage. Highly compensated employees might insist on tax-favored employer-provided pensions for the usual selfinterested reasons, and employers faced with effective nondiscrimination rules could comply with those demands only by providing pensions for rank-and-file workers as well.

The 1942 rules, however, included an exception to the nondiscrimination rules that deprived them of almost all force. An employer's plan was not considered discriminatory merely because it excluded from coverage employees whose compensation did not exceed the Social Security wage base of $\$ 3000$. $^{308}$ Since only about $3 \%$ of workers had earnings of more than $\$ 3000$, this so-called integration rule made it possible to exclude the vast majority of workers without running afoul of the nondiscrimination rules. ${ }^{309}$ More than four decades later, the Tax Reform Act of 1986 modified the integration rule; under the modified rule, pension benefits for workers with earnings below the Social Security wage base could be reduced without violating the nondiscrimination rules, but could not be eliminated.$^{310}$ After the 1986 Act, then, it is plausible that pension coverage would be somewhat lower in the absence of the nondiscrimination rules.

The nondiscrimination rules, however, have no relation to the question whether the income tax is a class tax or a mass tax. Although the 1942 Act both

305. HACKER, supra note 186, at 126-34.

306. The board's position was upheld in Inland Steel Co. v. NLRB, 170 F.2d 247 (7th Cir. 1948), cert. denied on this issue, 336 U.S. 960 (1949), aff'd on other grounds, Steelworkers v. NLRB, 339 U.S. 382 (1950).

307. Revenue Act of 1942, Pub. L. No. 77-753, § 162, 56 Stat. 798, 862.

308. Id.

309. HACKER, supra note 186, at 118.

310. Tax Reform Act of 1986, Pub. L. No. 99-514, § 1111, 100 Stat. 2085, 2435 (1986) (codified as I.R.C. $\S 401(l)$ ). For descriptions and critiques of the 1986 revisions, see Nancy J. Altman, Rethinking Retirement Income Policies: Nondiscrimination, Integration, and the Quest for Worker Security, 42 TAX L. REV. 435, 486-94 (1987); Dilley, supra note 299, at 1171-79. 
introduced the nondiscrimination rules and greatly expanded the scope of the income tax, the pairing was a coincidence. Nothing in the logic of nondiscrimination rules requires a mass income tax for the rules to be effective. As long as highly compensated employees are subject to the income tax, Congress can (if it chooses) encourage broad pension coverage by conditioning favorable income-tax treatment of the pensions of the highly compensated on the provision of pensions to the rank and file. It is immaterial for this purpose whether the rank-and-file employees are also subject to the income tax.

Since the favorable income-tax treatment of employer pensions predated by many years the conversion of the income tax to a mass tax, and since the growth of private-pension coverage is adequately explained by causes (both tax and nontax) other than the postwar existence of a mass income tax, it is reasonable to conclude that the income-tax pension rules and the extent of pension coverage would be roughly the same today under a retail sales tax (or VAT) and an elite income tax, as under the mass income tax.

Some commentators have suggested that the entire system of employer pensions would unravel if the United States were to repeal the federal income tax in its entirety and replace it with a VAT or retail sales tax. ${ }^{311}$ In the absence of any federal income tax-mass or elite-all savings would automatically receive the same favorable tax treatment available only for qualified retirement savings under the income tax. All amounts a worker saved for future consumption, and all investment returns on those amounts, would be exempt from the VAT until the worker converted the savings to consumption. Thus, as one commentator has noted, "Employer-provided pension plans [would] lose their monopoly on favorable tax treatment. Given that employer pension plans are expensive to administer, employers and employees may both decide that they are better off letting workers save for their own retirement independent of the workplace." ${ }^{\prime 12}$

Of course, many workers currently covered by employer pensions might lack the financial discipline to invest the resulting increase in cash wages in individual retirement savings; the danger might be especially acute for nonhighly compensated employees. ${ }^{313}$ This threat of unraveling of employer pensions (perhaps without adequate replacement by individual retirement savings) relates, however, to the complete repeal of the income tax. As long as the income tax is retained for higher-income earners, those earners will continue to demand employment-based pensions for themselves-and for others, if nondiscrimination rules make their own favorable tax treatment dependent on the provision of employer pensions to the rank and file.

There remains one final argument as to why the favorable income-tax treatment of employer pensions might have been at risk under a postwar elite

311. See, e.g., Julie Roin, The Consequences of Undoing the Federal Income Tax, 70 U. CHI. L. REV. 319,328 (2003).

312. Id.

313. Id. at 328-29. 
income tax. This argument parallels the one made earlier with respect to the home-mortgage-interest deduction. ${ }^{314}$ Perhaps the extent to which the benefits of the income-tax treatment of employer pensions are skewed toward the rich is masked under a mass income tax because the same formal rules apply to the pensions of taxpayers at all income levels. Under a class income tax, by contrast, it would be obvious that the favorable income-tax rules for employer pensions benefit only the affluent minority subject to the income tax. With the distributional consequences of the rules laid bare, perhaps the public would demand repeal of those rules.

An outcome along those lines would be quite likely with respect to the home-mortgage-interest deduction. It would be much less likely, however, with respect to employer pensions. The home-mortgage-interest deduction is readily understood by the public as a government subsidy to the owners of mortgaged homes; in effect, the federal government pays a percentage of the homeowner's interest expense equal to the homeowner's marginal tax rate. With this understanding of the deduction, less-affluent homeowners not subject to the income tax could be expected to ask why the government is paying a portion of the home-mortgage-interest expense of the rich, but is not paying any portion of their own interest expense.

There are three salient differences between home-mortgage interest and pensions that, taken together, make it unlikely that similar protests would be raised in the pension context. First, it is much less clear in the case of pensions than in the case of mortgage interest that the public understands the favorable income-tax treatment as a subsidy. This follows from the differing visibility levels of deductions and exclusions; it is easier to see the tax savings from a deduction than the tax savings from an exclusion. Second, even if people not subject to the class income tax viewed the income-tax treatment of pensions as a subsidy, proponents of retaining the income-tax treatment could explain that the resulting tax treatment of the retirement savings of the affluent is no different from the tax treatment under the retail sales tax (or VAT) of the retirement savings of the masses. Under both the income tax and the sales tax, retirement savings is taxed once-when consumed in retirement. By contrast, there would seem to be no chance of persuading the masses that they somehow receive the functional equivalent of a home-mortgage-interest deduction under the sales tax. Third, to the extent that the nondiscrimination rules promote pension coverage for rank-and-file workers not subject to the income tax, defenders of the favorable income-tax treatment of pensions could argue that rank-and-file workers were indirect beneficiaries of the income-tax rules. Again by contrast, defenders of the home-mortgage-interest deduction under a class income tax could not hope to convince those not subject to the income tax that they were the indirect beneficiaries of the deduction.

314. See supra text accompanying notes 283-300 (arguing that the home-mortgage-interest deduction would be in peril under a class income tax). 


\section{$\mathrm{V}$ \\ CONCLUSION}

Perhaps the story of the sales-tax-that-wasn't lends some support to the Great Man theory of history. But for President Roosevelt's condemnation of a retail sales tax-on distributional grounds that do not stand up under examination-the federal tax structure today might be very different. The speculations offered here concerning how the postwar federal tax system might have developed differently under the combination of a retail sales tax and a class income tax-even assuming the distributional equivalence of the two-tax system with the actual mass income tax as of the end of World War II-are not solely an exercise in alternate history for its own sake. In evaluating present-day proposals (such as that of Michael Graetz ${ }^{315}$ ) to introduce a retail sales tax or VAT and to return the income tax to its class-tax origins, it is necessary to consider more than the initial distribution of tax burdens under the proposal and the prospect of eliminating "100 Million Unnecessary Returns." Even if the two-tax system at its inception is distributionally identical with the mass income tax it replaces, the effects of the change in later years may be wide-ranging indeed. Decades hence, everything from federal policy toward low-wage workers with children, to housing policy, to the overall distribution of the federal tax burden, may depend on whether the United States retains a mass income tax or returns the income tax to its more modest prewar status.

315. Graetz, supra note 185. 